\title{
Giant calcite concretions in aeolian dune sandstones; sedimentological and architectural controls on diagenetic heterogeneity, mid-Cretaceous Iberian Desert System, Spain
}

\author{
Maria Eugenia Arribas a , Juan Pedro Rodríguez-López b,*, Nieves Meléndez ${ }^{\text {c }}$, \\ Ana Rosa Soria a, Poppe L. de Boer ${ }^{\mathrm{e}}$ \\ a Departamento de Petrologia y Geoquimica-Instituto de Geociencias (UCM-CSIC), Facultad de Ciencias Geológicas, Universidad Complutense de Madrid, Ciudad Universitaria, \\ 28040 Madrid, Spain \\ ${ }^{b}$ Grupo de Análisis de Cuencas Sedimentarias (UCM-CAM), Departamento de Estratigrafia, Facultad de Ciencias Geológicas, Universidad Complutense de Madrid, \\ Ciudad Universitaria, 28040 Madrid, Spain \\ ${ }^{c}$ Grupo de Análisis de Cuencas Sedimentarias (UCM-CAM), Departamento de Estratigrafia-Instituto de Geociencias (UCM-CSIC), Facultad de Ciencias Geológicas, \\ Universidad Complutense de Madrid, Ciudad Universitaria, 28040 Madrid, Spain \\ a Grupo de Análisis de Cuencas Sedimentarias Continentales (DGA), Departamento de Ciencias de ia Tierra, Facuitad de Ciencias, Universidad de Zaragoza, \\ C/Pedro Cerbuna 12, 50009, Zaragoza, Spain \\ e Sedimentology Group, Department of Earth Sciences, Utrecht University, Budapestiann 4, 3584 CD Utrecht, The Netheriands
}

Keywords:

Giant calcite concretions

Aeolian sandstones

Porosity

Reservoir

Carbonate cements

Heterogeneity

\begin{abstract}
A B S T R A C T
Aeolian dune sandstones of the Iberian erg system (Cretaceous, Spain) host giant calcite concretions that constitute heterogeneities of diagenetic origin within a potential aeolian reservoir. The giant calcite concretions developed in large-scale aeolian dune foresets, at the transition between aeolian dune toeset and damp interdune elements, and in medium-scale superimposed aeolian dune sets. The chemical composition of the giant concretions is very homogeneous. They formed during early burial by low $\mathrm{Mg}$-calcite precipitation from meteoric pore waters. Carbonate components with yellow/orange luminescence form the nuclei of the poikilotopic calcite cement. These cements postdate earlier diagenetic features, characterized by early mechanical compaction, $\mathrm{Fe}$-oxide cements and clay rims around windblown quartz grains resulting from the redistribution of aeolian dust over the grain surfaces. The intergranular volume (IGV) in friable aeolian sandstone ranges from 7.3 to $15.3 \%$, whereas in cemented aeolian sandstone it is 18.6 to $25.3 \%$. The giant-calcite concretions developed during early diagenesis under the influence of meteoric waters associated with the groundwater flow of the desert basin, although local (e.g. activity of fluid flow through extensional faults) and/or other regional controls (e.g. variations of the phreatic level associated with a variable water influx to the erg system and varying sea level) could have favoured the local development of giant-calcite concretions. The spatial distribution pattern of carbonate grains and the main bounding surfaces determined the spatial distribution of the concretions. In particular, the geometry of the giant calcite concretions is closely associated with main bounding aeolian surfaces. Thus, interdune, superimposition and reactivation surfaces exerted a control on the concretion geometries ranging from flat and tabular ones (e.g. bounded by interdunes) to wedge-shaped concretions at the dune foresets (e.g. bounded by superimposition and reactivation surfaces) determining the spatial distribution of the heterogeneities of diagenetic origin in the aeolian reservoir.
\end{abstract}

\section{Introduction}

Giant calcite concretions occur in high-porosity sandstones in different sedimentary environments including fluvial and deltaic settings (Bjorkum and Walderhaug, 1990; Beckner and Mozley, 1998;

\footnotetext{
* Corresponding author at: Department of Stratigraphy, Faculty of Geological Sciences, Universidad Complutense de Madrid, Ciudad Universitaria, 28040, Madrid, Spain. Tel/fax: +34 679089851.

E-mail addresses: earribas@geo.ucm.es (M.E. Arribas), jprodrig@geo.ucm.es (J.P. Rodríguez-López).
}

Milliken, 1998; Walderhaug and Bjorkum, 1998; Abdel-Wahab and McBride, 2001; McBride et al., 2003). Well known examples include the so-call cannonball concretions (each up to $6 \mathrm{~m}$ in diameter) in (tide-influenced?) fluvial deposits in the Theodore Roosevelt National Park in North Dakota (McBride and Milliken, 2006), concretions of $2 \mathrm{~cm}$ to $6 \mathrm{~m}$ in shelf sandstones of the Ferron Sandstone Member, and the Frontier Sandstone Formation (McBride et al., 2003), and giant-calcite concretions in the Temple Member (Eocene, Egypt) (Abdel-Wahab and McBride, 2001). Each of these examples shows a significant porosity reduction relative to the host rocks. The elevated porosity and permeability of aeolian dune sandstones make these 
deposits prone to developed heterogeneities of diagenetic origin as concretions. Ancient windblown deposits form volumetrically considerable reservoirs (Glennie, 1986) in several hydrocarbon provinces (e.g. in the southern North Sea the Permian Rotliegend Group that constitutes the principal gas reservoir, and oil reservoirs occur in the central North Sea sandstones of this group, e.g. Glennie and Buller, 1983; Kugler and Mink, 1999; Heward et al., 2003) and diagenetic heterogeneities constitute important baffles for hydrocarbon migration. Howell and Mountney (2001) point out that with the advent of 3D reservoir modelling, flow simulation techniques and the
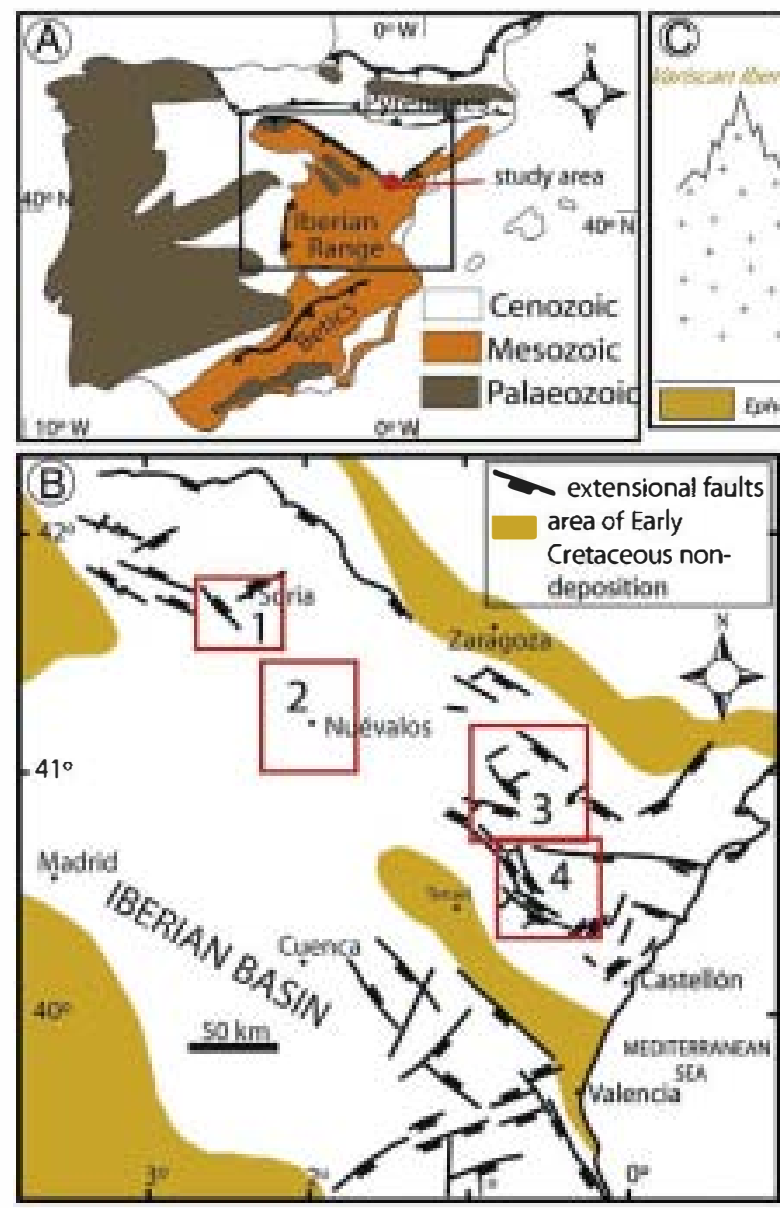

\section{Legend}

-- mudstones

coaly mudstones

$\square$ siltstones

sandstones

$\triangle$ aeolian dune foreset

$\approx$ aeolian dune toeset

dry interdune

C2 giant-calcite concretions
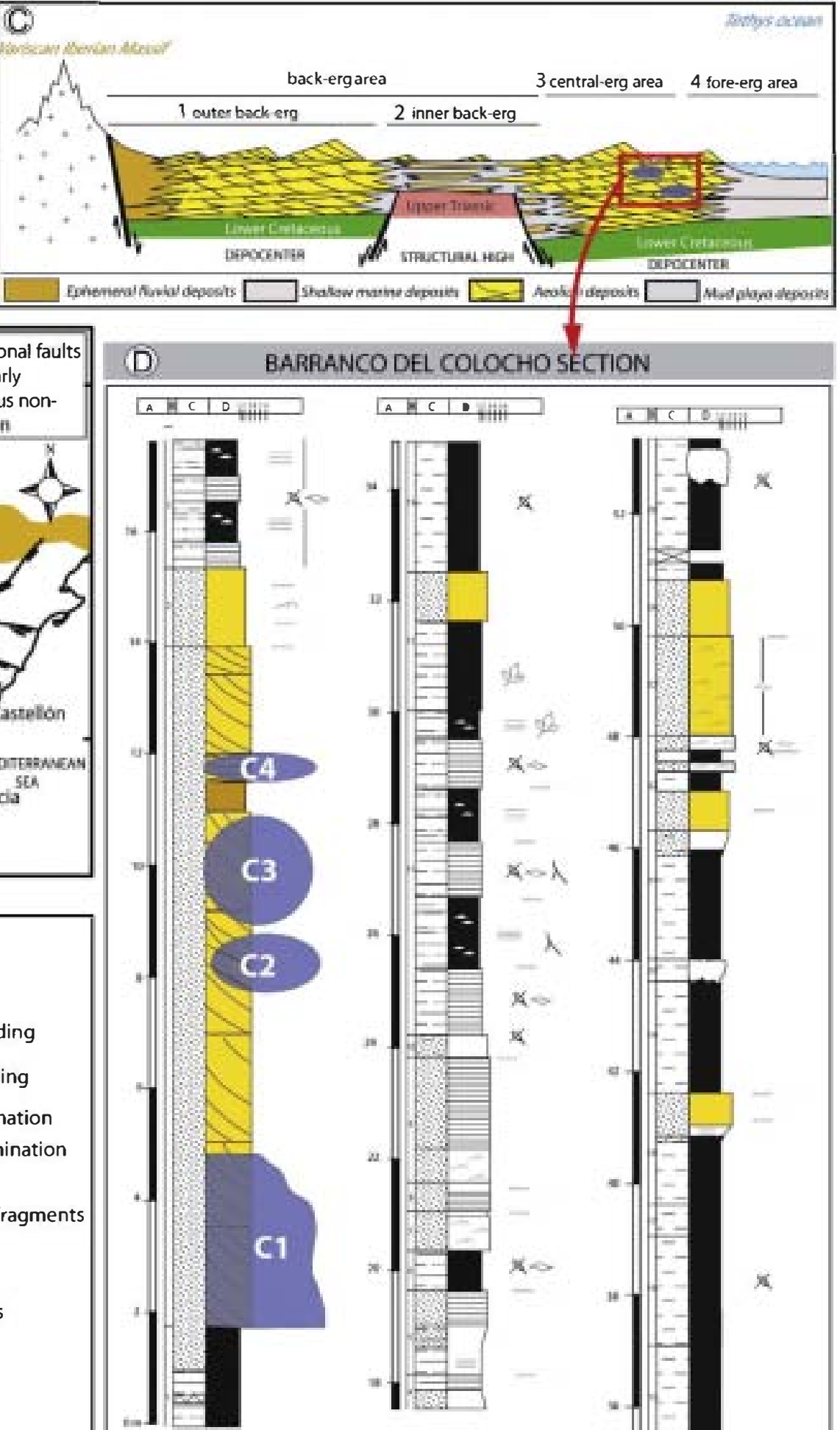

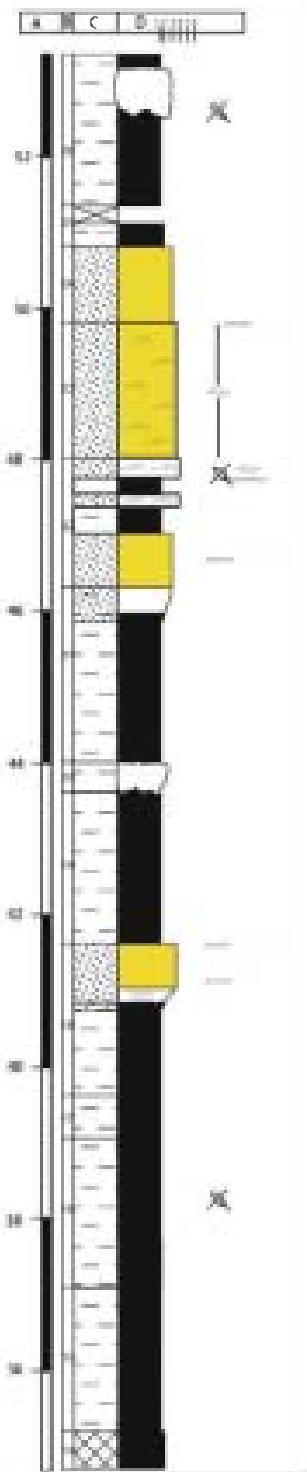

Fig. 1. (A) The Iberian Range (eastern Spain). (B) Palaeogeography of the Cretaceous Iberian Basin with main areas of deposition, highlands and principal synsedimentary faults (modified after Liesa et al., 2004). 1,2 and 3 highlight the location of schematic sections in (C). (C) The spatial zonation of the erg system and the location of giant calcite concretions in the aeolian dune deposits of the central-erg area close to the limit with the fore-erg zone. (D) Barranco del Colocho stratigraphic section with the giant calcite concretions (C1-C4). 
switch to tertiary production methods, quantitative data are needed on various aspects of aeolian reservoir architecture to be obtained from suitable outcrop-based analogues. In such a way, this paper provides the description and interpretation of exceptional outcrops of giant calcite concretions in compound aeolian dunes in the midCretaceous Iberian Desert System that constitute a suitable analogue
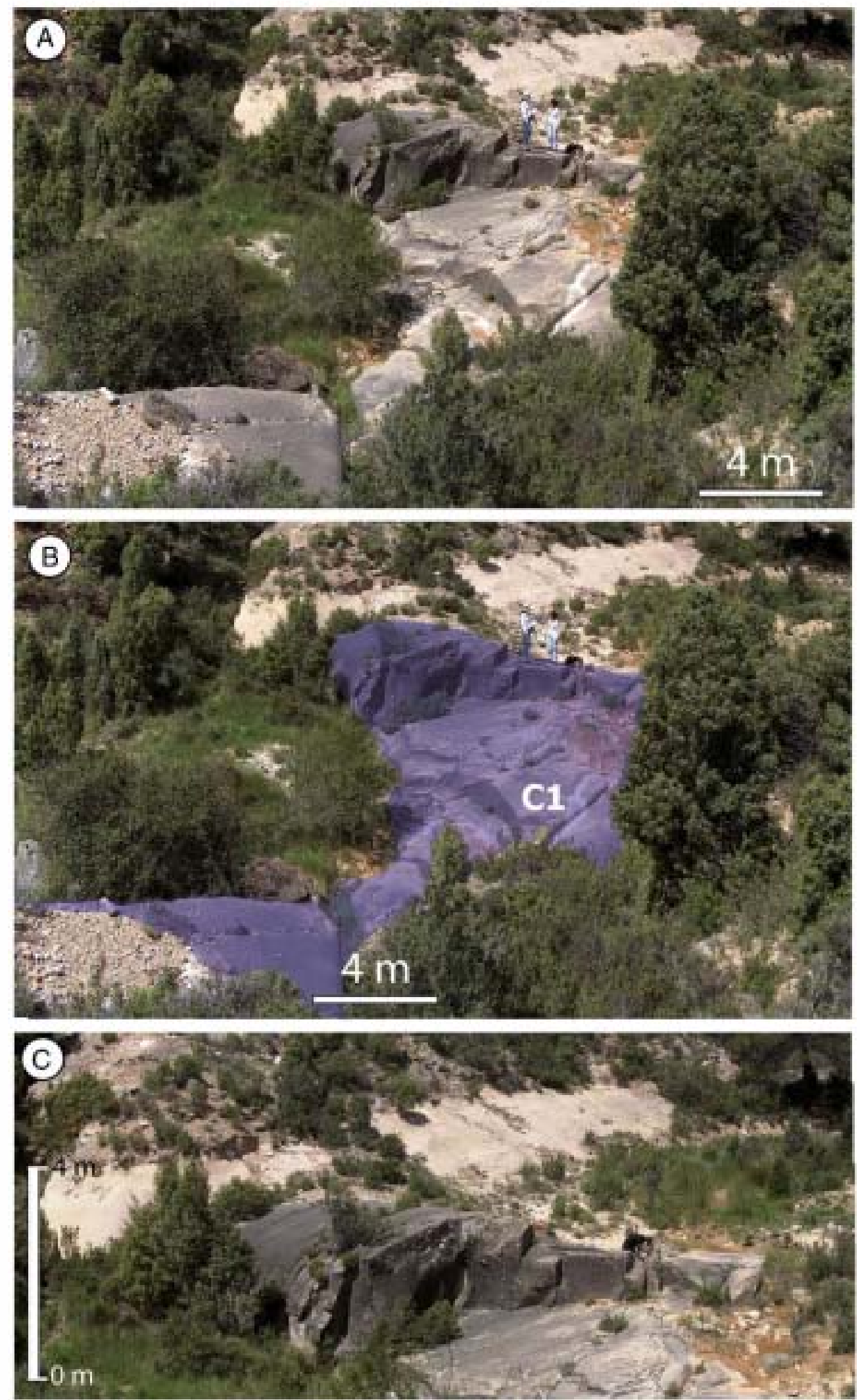

Fig. 2. Giant calcite concretion C1. (A) Field photograph and (B) giant calcite concretion highlighted with a blue overlay. (C) Close up of (A). Concretion $\mathrm{C} 1$ is $4 \mathrm{~m}$ thick, displays a nodular-tabular geometry and extends over an area of about $300 \mathrm{~m}^{2}$. This giant calcite concretion developed in crescentic aeolian dune trough cross-bedded sets. 


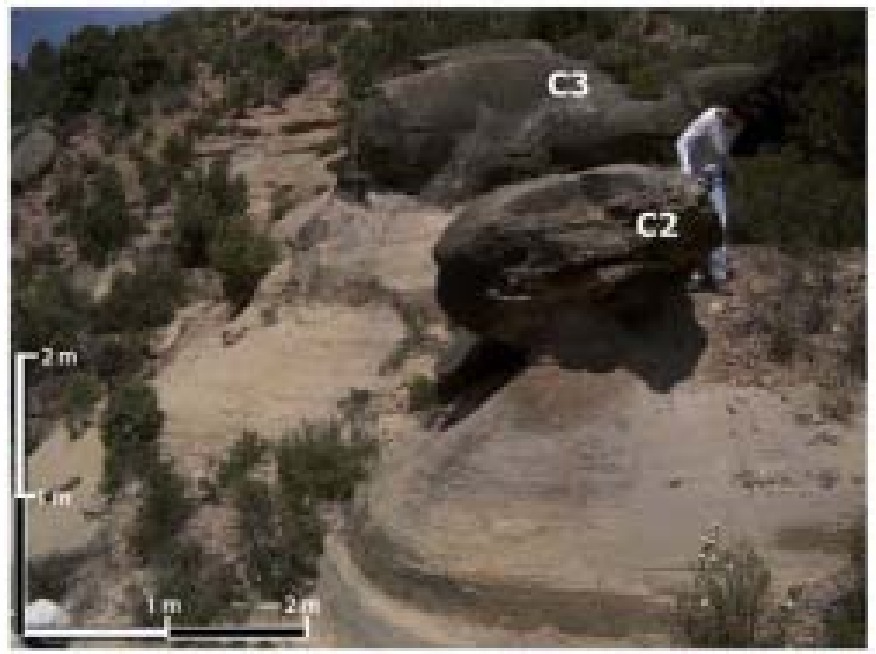

Fig. 3. Giant calcite concretions $C 2$ and $C 3$. Concretion $C 2$ developed in superimposed aeolian dune trough cross-bedded sets interbedded with non-cemented large scale aeolian dune foresets below and with cemented (concretion C3) large scale aeolian dune foresets above.

for subsurface aeolian units that acts as hydrocarbon reservoirs. Giant-calcite concretions are described, in petrological and sedimentological terms. Special attention is paid in the architectural control of aeolian bounding surfaces on giant-calcite concretion geometries.

\section{The mid-Cretaceous Iberian erg}

An early Albian to early Cenomanian aggrading sandy desert system characterized the Iberian Basin between the Tethys Ocean to the east and the highland Iberian Massif to the west (Fig. 1) (Rodríguez-López et al., 2008). This desert system extended over an area of more than $16,000 \mathrm{~km}^{2}$. During the Albian-Cenomanian Iberia occupied a position in the Northern Hot Arid Belt (NHA) at a palaeolatitude of $25^{\circ}-30^{\circ} \mathrm{N}$ (Chumacov et al., 1995; Stampfli and Borel, 2002; Spicer and Skelton, 2003; Rodríguez-López et al., 2006). The mid-Cretaceous Iberian Desert System displays a three-fold spatial division with well defined back-erg, central-erg and fore-erg areas (Rodríguez-López et al., 2010; Rodríguez-López et al., in press) (Fig. 1C and D).

The continental back-erg system (Fig. 1C and D) was close to the highland Iberian Massif (to the west) and was characterized by processes associated with mixed wind-water interaction processes that led to the accumulation and preservation of a variety of facies associations including those arising from debris flow and hyperconcentrated flow processes in wadi channels, and those arising from wind activity including the generation of deflation lags, desert pavements with ventifacts, aeolian dunes and aeolian sandsheets (RodríguezLópez et al., 2010). This erg margin system was subjected to episodic water influxes via ephemeral streams, which reworked desert pavements and aeolian dune sands thereby forming hyperconcentrated flows. An (intermittently) glaciated Variscan Mountain belt in combination with monsoonal water discharge and dune damming favoured such processes (Rodríguez-López et al., 2010).

The central-erg area is characterized by complex aeolian dunes (slip faceless draas) (e.g. McKee, 1979), climbing crescentic dunes, linear draas and damp, wet and dry interdunes (Rodríguez-López et al., 2008). Synsedimentary tectonics generated supersurfaces that separate different erg sequences (Rodríguez-López et al., 2008).

The marine fore-erg (Fig. 1C and D) was subject to aeolian-marine interaction (Rodríguez-López et al., in press). Coeval marine sedimentary environments in the adjacent Tethys received and reworked
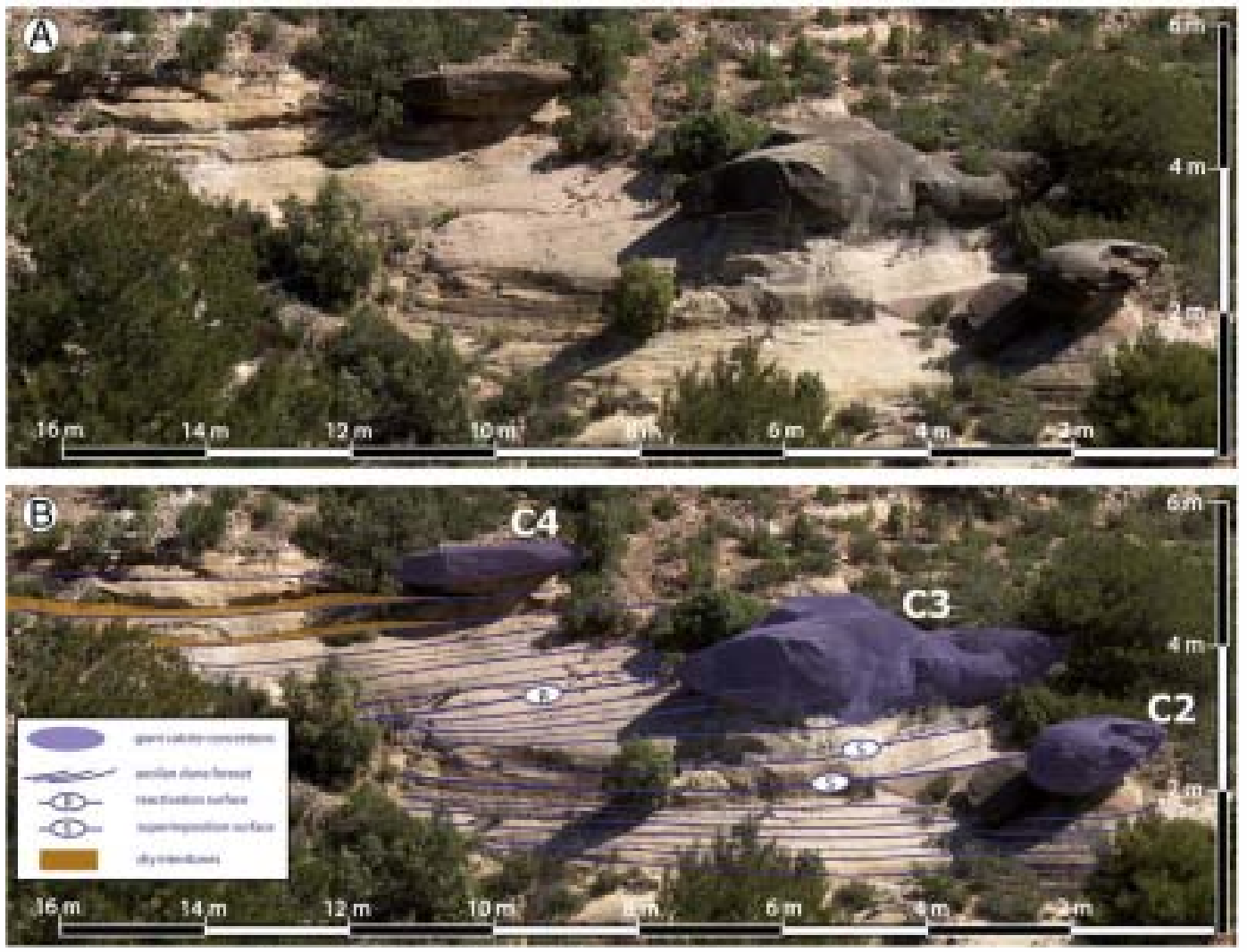

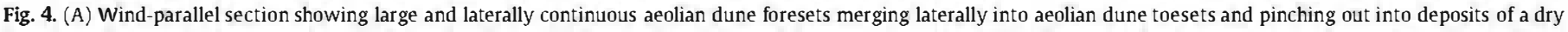

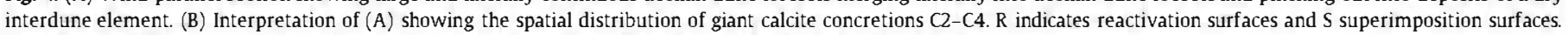
Note that the different morphology of concretions depends on the aeolian elements in which they developed. 
large volumes of windblown sand from the erg-margin system (Rodriguez-López et al., 2006). The close proximity of the Tethys favoured a high groundwater table and this contributed to the preservation of the aeolian facies (Rodríguez-López et al., 2008). The marine fore-erg system was characterized by aeolian dunes, aeolian duneextradune (lagoon) cycles, sandy sabkhas, playa-lake systems and massive sandstone deposits interbedded with aeolian dunes, interpreted as sandy mass-flow deposits resulting from (catastrophic) flooding (Rodríguez-López et al., in press) (cf. Glennie and Buller, 1983; Strömbäck et al., 2005).

Here the focus is on giant calcite concretions from The Barranco del Colocho section (Teruel Province, Fig. 1E and F) that developed in compound aeolian dune sands in the boundary zone of the central erg and the fore-erg (Fig. 1D).

\section{Methods}

Facies analyses in Rodríguez-López et al. (2006, 2008, 2010, in press) provide the reference framework for the data presented here. The studied outcrop is the Barranco del Colocho outcrop located near the village of Estercuel and that shows giant-calcite concretions (Figs. 1F, 2-6). These concretions occur in four stratigraphic levels (C1-C4, Fig. 1F) in porous and friable sandstone. The lowermost
(C1) is the largest concretion (at least $25 \mathrm{~m}$ long, $4 \mathrm{~m}$ high and more than $3 \mathrm{~m}$ broad) and forms a laterally continuous nodulartabular body (Fig. 2). In the upper levels C2 and C3, calcite concretions form isolated spheroid bodies ( 1 to $2 \mathrm{~m}$ thick) (Figs. 3 and 4 ). The uppermost concretion $\mathrm{C} 4$ is $0.5 \mathrm{~m}$ thick and displays a tabular geometry (Fig. 4).

Twenty two samples were taken from the Cemented Aeolian Sandstones (CAS - the concretions) and the Friable Aeolian Sandstones (FAS - the host rock). Polarized light and scanning electron microscopy (SEM) were used to determine the petrological properties of the samples. Thin sections were prepared using standard procedures (Friedman, 1971; linholm and Finkelman, 1972; Norman, 1974) including: (1) impregnation with blue epoxy resin to highlight porosity in thin sections and (2) selective staining and etching for the identification of feldspar (Friedman, 1971; Norman, 1974) and carbonate (Linholm and Finkelman, 1972). Cathodoluminescence (CL) examination was carried out using a Technosyn cold cathodoluminescence unit operating at $17-20 \mathrm{kV}$ with $300 \mu \mathrm{A}$ beam current. Petrological characterization included composition, texture and diagenesis. Grain-size analyses were carried out by point counting using the Gazzi-Dickinson method (Ingersoll et al., 1984). The relative abundance of lithic grains (rock fragments) was determined by modal analyses of 300 to 400 point counts in each thin section. Additionally, the intergranular volume

Table 1

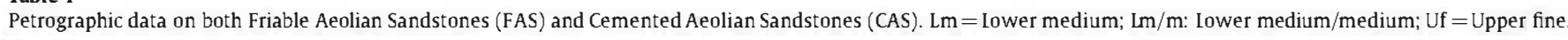

\begin{tabular}{|c|c|c|c|c|c|c|c|c|c|c|c|c|c|c|c|c|c|}
\hline \multicolumn{18}{|l|}{ Sample } \\
\hline \multirow[t]{3}{*}{ Cemented } & \multirow{3}{*}{$\frac{\text { Friable }}{\text { Texture }}$} & \multirow{2}{*}{\multicolumn{2}{|c|}{$\frac{\mathrm{C} 1-1}{\mathrm{Lm} / \mathrm{m}}$}} & \multirow{2}{*}{\multicolumn{2}{|c|}{$\frac{\mathrm{C} 1-\mathrm{T}}{\mathrm{Lm}}$}} & \multirow{2}{*}{\multicolumn{2}{|c|}{$\frac{\mathrm{C} 2-1}{\mathrm{Lm}}$}} & \multirow{2}{*}{\multicolumn{2}{|c|}{$\frac{\mathrm{C} 2-2}{\mathrm{Lm}}$}} & \multirow{2}{*}{\multicolumn{2}{|c|}{$\frac{\mathrm{C} 3-1}{\mathrm{Uf}}$}} & \multirow{2}{*}{\multicolumn{2}{|c|}{$\frac{\mathrm{C} 3-3}{\mathrm{Lm}}$}} & \multirow{2}{*}{\multicolumn{2}{|c|}{$\frac{\mathrm{C} 4-1}{\mathrm{Uf}}$}} & \multirow{2}{*}{\multicolumn{2}{|c|}{$\frac{C 4 b}{U f}$}} \\
\hline & & & & & & & & & & & & & & & & & \\
\hline & & Point & $\%$ & Point & $\%$ & Point & $\%$ & Point & $\%$ & Point & $\%$ & Point & $\%$ & Point & $\%$ & Point & $\%$ \\
\hline \multirow[t]{9}{*}{ Q } & $\begin{array}{l}\text { Qms quartz monocrystalline, } \\
\text { undulosity }<5^{\circ}\end{array}$ & 68 & 22.7 & 78 & 26 & 75 & 25.0 & 85 & 28.3 & 109 & 36.3 & 95 & 31.7 & 59 & 19.7 & 67 & 22.3 \\
\hline & $\begin{array}{l}\text { Qmu quartz monocrystalline, } \\
\text { undulosity }>5^{\circ}\end{array}$ & 21 & 7 & 11 & 3.67 & 11 & 3.7 & 7 & 2.33 & 7 & 2.33 & 12 & 4 & 15 & 5 & 23 & 7.67 \\
\hline & $\begin{array}{l}\text { Qp2-3 quartz polycrystalline } 2-3 \\
\text { subgrains }\end{array}$ & 8 & 2.7 & 4 & 1.33 & 12 & 4.0 & 8 & 2.67 & 6 & 2 & 8 & 2.67 & 8 & 2.67 & 6 & 2 \\
\hline & $\begin{array}{l}\text { Qp }>3 \text { quartz polycrystalline }>3 \\
\text { subgrains }\end{array}$ & 10 & 3.3 & 10 & 3.33 & 5 & 1.7 & 12 & 4 & 4 & 1.33 & 8 & 2.67 & 1 & 0.33 & 0 & 0 \\
\hline & Qin $\mathrm{Rg}$ & 0 & 0 & 1 & 0.33 & 1 & 0.3 & 3 & 1 & 0 & 0 & 3 & 1 & 0 & 0 & 2 & 0.67 \\
\hline & MQ metaquartzite & 4 & 1.3 & 2 & 0.67 & 4 & 1.3 & 11 & 3.67 & 3 & 1 & 9 & 3 & 7 & 2.33 & 12 & 4 \\
\hline & {$[\mathrm{Cm}$ in $\mathrm{Qm}]$} & 13 & 4.3 & & & 24 & 8.0 & & & 17 & 5.67 & & & 26 & 8.67 & & \\
\hline & [Cmin MQ] & 2 & 0.7 & & & 1 & 0.3 & & & 2 & 0.67 & & & 0 & & & \\
\hline & & 126 & 42.0 & 106 & 35.3 & 133 & 44.3 & 126 & 42 & 148 & 49.3 & 135 & 45 & 116 & 38.7 & 110 & 36.7 \\
\hline \multirow[t]{6}{*}{$\mathrm{F}$} & K K-feldspar (ortose + microdine) & 56 & 18.7 & 69 & 23 & 38 & 12.7 & 62 & 20.7 & 35 & 11.7 & 59 & 19.7 & 27 & 9 & 57 & 19 \\
\hline & $\mathrm{K}$ in $\mathrm{Rg}$ & 1 & 0.3 & 1 & 0.33 & 1 & 0.3 & 2 & 0.67 & 0 & 0 & 1 & 0.33 & 0 & 0 & 0 & 0 \\
\hline & P Plagioclase & 13 & 4.3 & 18 & 6 & 8 & 2.7 & 10 & 3.33 & 8 & 2.67 & 5 & 1.67 & 8 & 2.67 & 9 & 3 \\
\hline & Albite & 3 & 1.0 & & & 0 & & & & 0 & & & & 0 & & & \\
\hline & {$[\mathrm{Cm}$ in $\mathrm{F}]$} & 8 & 2.7 & & & 7 & 2.3 & & & 8 & 2.7 & & & 11 & 3.67 & & \\
\hline & & 81 & 27.0 & 88 & 29.3 & 54 & 15.7 & 74 & 24.7 & 51 & 14.3 & 65 & 21.7 & 46 & 15.3 & 68 & 22 \\
\hline \multirow[t]{2}{*}{$\mathrm{R}$} & Rm Schist + slate + chert & 1 & 0.3 & 4 & 1.33 & 3 & 1.0 & 2 & 0.67 & 3 & 1 & 3 & 1 & 0 & 0 & 5 & 1.67 \\
\hline & & & 0.3 & & 1.33 & & 1.0 & & 0.67 & & 1 & & 1 & & 0 & & 1.67 \\
\hline$?$ & Calcified grains (nuclei) in cement & 17 & 5.7 & 0 & 0 & 19 & 6.3 & 0 & 0 & 11 & 3.67 & 0 & 0 & 20 & 6.67 & 0 & 0 \\
\hline \multirow[t]{2}{*}{ M } & Muscovite & 7 & 2.3 & 4 & 1.33 & 8 & 2.7 & 9 & 3 & 3 & 1 & 8 & 2.67 & 7 & 2.33 & 7 & 2.33 \\
\hline & Biotite + chlorite & 0 & 0 & 0 & 0 & 2 & 0.7 & 0 & & 0 & 0 & 2 & 0.67 & 3 & 1 & 0 & 0 \\
\hline \multirow[t]{2}{*}{ Acc } & Tourmaline & 0 & 0 & 0 & 0 & 0 & 0.0 & 0 & 0 & 1 & 0 & 0 & 0 & 0 & 0 & 1 & 0.33 \\
\hline & Opaque & 5 & 1.67 & 4 & 1.33 & 8 & 2.7 & 7 & 2.33 & 12 & 4 & 21 & 7 & 23 & 7.67 & 38 & 12.7 \\
\hline \multirow[t]{2}{*}{$\mathrm{NCI}$} & $\begin{array}{l}\text { Shaly and silty intraclasts } \\
\text { (diagenetic matrix) }\end{array}$ & 0 & & 0 & & 0 & & 2 & 0.67 & 3 & 1 & 8 & 2.67 & 3 & I & 11 & 3.67 \\
\hline & $\begin{array}{l}\text { Kaolinite replacing shaly and silty } \\
\text { intraclasts }\end{array}$ & 0 & & 2 & 0.67 & 0 & & 5 & 1.67 & 0 & 0 & I & 0.33 & 0 & 0 & 0 & 0 \\
\hline $\mathrm{Cm}$ & $\begin{array}{l}\text { [Calcite in cement] } \\
\text { [Opaque cement] }\end{array}$ & $\begin{array}{r}51 \\
\mathrm{I}\end{array}$ & 17.0 & 0 & 0 & 66 & 22.0 & 0 & 0 & 58 & 19.3 & 0 & 0 & 70 & 23.3 & 0 & 0 \\
\hline \multicolumn{2}{|l|}{ Porosity } & 11 & 3.7 & 92 & 30.7 & 7 & 2.3 & 75 & 25 & 10 & 3.33 & 57 & 19 & 12 & 4 & 62 & 20.7 \\
\hline \multicolumn{2}{|l|}{ Total } & 300 & 99.7 & 300 & 100 & 300 & 100 & 300 & 100 & 300 & 99.7 & 300 & 100 & 300 & 100 & 300 & 100 \\
\hline \multirow{2}{*}{\multicolumn{2}{|c|}{ Intergranular volume [cement + porosity] }} & 62 & 20.7 & 92 & 30.7 & 73 & 24.3 & 75 & 25 & 68 & 22.7 & 57 & 19 & 82 & 27.3 & 62 & 20.7 \\
\hline & & $C-1$ & & & & $C-2$ & & & & $C-3$ & & & & $C-4$ & & & \\
\hline \multicolumn{2}{|l|}{ Qm } & 126 & 60.6 & 106 & 53.5 & 133 & 70 & 126 & 62.4 & 148 & 73.3 & 135 & 68.5 & 116 & 71.6 & 110 & 60.8 \\
\hline $\mathrm{F}$ & & 81 & 38.9 & 88 & 44.4 & 54 & 28.4 & 74 & 36.6 & 51 & 25.2 & 65 & 32.0 & 46 & 28.4 & 66 & 36.5 \\
\hline $\mathrm{Lt}$ & & 1 & 0.5 & 4 & 2.0 & 3 & 1.6 & 2 & 1.0 & 3 & 1.5 & 3 & 1.5 & 0 & 0 & 5 & 2.8 \\
\hline
\end{tabular}



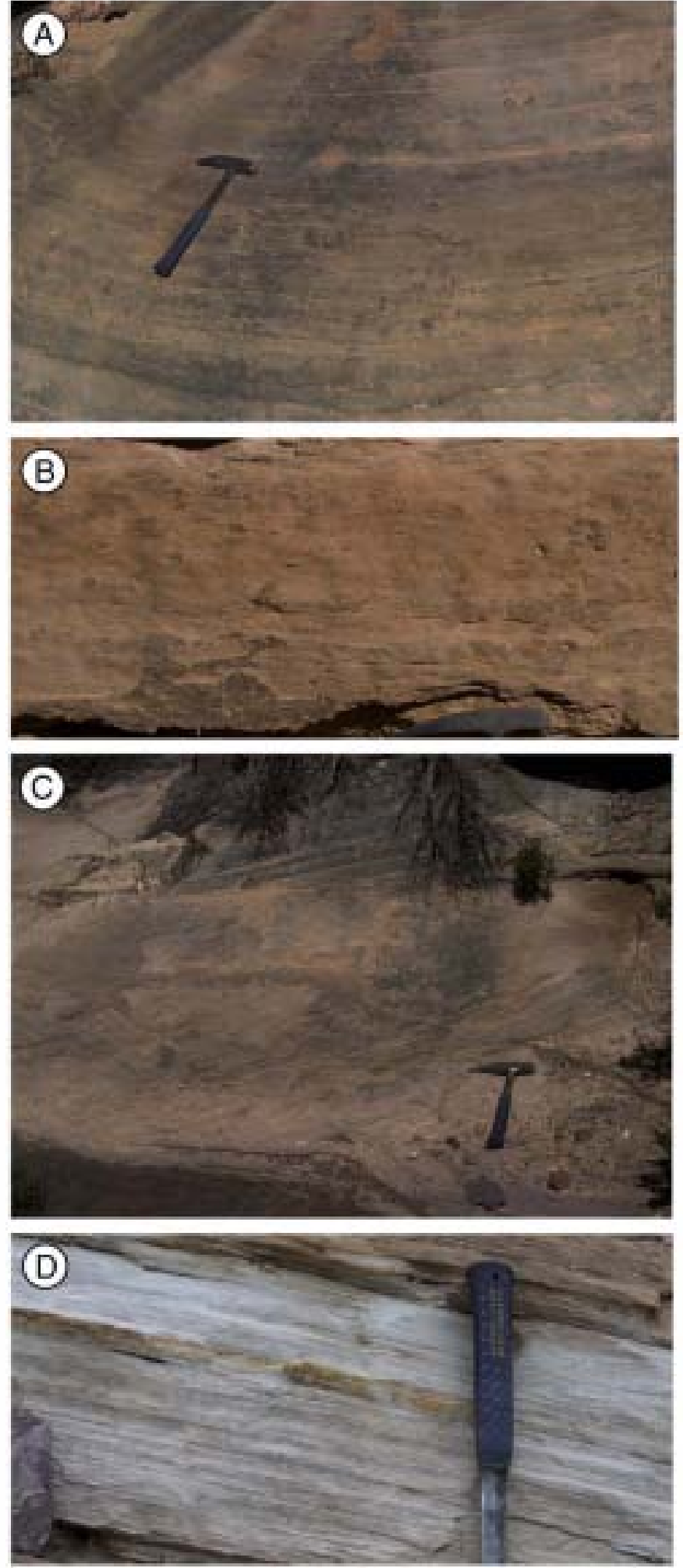

Fig. 5. Aeolian elements. (A) Grainflow and grainfall deposits in a large dune foreset. (B) Wavy bedding in the aeolian dune toeset-damp interdune element. (C) Superimposed sets of aeolian dune elements. (D) Dry interdune sandstones organized in subcritically climbing translatent strata due to wind ripple migration and accumulation.

(IGV) was estimated. In FAS, the IGV is considered the remnant primary porosity after early mechanical compaction, whereas in CAS, IGV corresponds to the sum of the remnant porosity plus the intergranular cement. All data were normalized to $100 \%$ (Table 1). From the data obtained in the counts and following Lundegard (1992), the loss of porosity by compaction (COPL) and by cementation (CEPL) were estimated assuming an original porosity in the aeolian sands of $40 \%$ (Beard and Weyl, 1973). Although it is known that windblown sand deposits vary in porosity considerably, according to these authors and considering the grain size (medium and fine) and the sorting of the original aeolian sands (very well sorted), the original porosity may be estimated between $40.2 \%$ and $39.8 \%$ (mean value $40 \%$ ). SEM analysis was performed using a Philips KL-20 scanning electron microscope equipped with an energy dispersive X-ray analyser (EDAX-DX-4i). Fresh fracture surfaces of the samples were gold covered. Major and trace-element contents were measured in individual calcite crystals of the calcite cement using electron microprobe analysis. These analyses and backscattered electron analyses were performed on polished and carbon-coated surfaces with a JEOL electron microprobe (JXA $8.900 \mathrm{M}$ ) equipped with four spectrometers at the Departmentof Stratigraphy of the Universidad Complutense de Madrid. The standards used are described by Jarosewich et al. (1980) and were provided by the Department of Mineral Sciences of the Smithsonian Institution (Washington).

Fluorescence microscopy (FM) analysis was used to identify illite grain coatings. The light source is a $100 \mathrm{~W}$ Olympus (U-RFL-T) mercury vapour lamp, and an Olympus BX-51 binocular microscope was used. Excitation of the illite crystal lattice is seen as yellow fluorescence. To assess the pore structure of the samples, connected or open porosity ( $\mathrm{P}$ ) and pore size distribution (PSD), Mercury Intrusion Porosimetry (MIP) was used. It was determined in an area of $0.001-1000 \mu \mathrm{m}$, with measurement conditions from atmospheric pressure to 60,000 psia (228 MPa).

\section{Aeolian dune and interdune elements}

\subsection{Large-scale aeolian dune foreset}

\subsubsection{Description}

This element is formed from fine-grained, very well sorted sandstones organized in large-scale tangential cross-bedded sets that contain foresets that can be followed laterally over more than $16 \mathrm{~m}$ (Fig. 4). Foresets consist of sets of laterally continuous dark-brown lamina packages, each 10 to $40 \mathrm{~mm}$ thick and several metres long (Fig. 3), alternating with millimetre-thick fine-grained sandy laminae with a characteristic white to pale colour (Fig. 5A). Foresets are truncated by laterally continuous, downwind-dipping concave-up surfaces ( $R$ in Fig. 4). Overlying laminae are parallel to these surfaces. Locally, large foresets are interbedded with intervals of mediumscale superimposed aeolian dune sets (described below). Large tangential foresets merge laterally into sandy tabular toesets and dry interdune deposits (both elements described below) (Fig. 4).

\subsubsection{Interpretation}

The thick accumulations of fine-grained very well sorted sandstones arranged in large-scale and laterally continuous tangential sets which themselves contain foresets are interpreted as aeolian dune slip-face deposits (Kocurek, 1991; Lancaster, 1995; Mountney, 2006a,b). Downwind-dipping concave-up surfaces marked ' $R$ ' in Fig. 4 are covered by concordant cross strata and are interpreted as reactivation surfaces (Brookfield, 1977; Kocurek, 1996; Mountney and Thompson, 2002) that developed due to wind reworking of dune foresets in periods of changing wind regimes (Kocurek, 1981, 1996). Aeolian dune foresets (Fig. 4) are arranged as stratum that are each 3 metres thick and 16 metres long (Fig. 5A) to signify deposition on a well developed slipface with a flow separation zone (cf. Kocurek, 1991; Scherer, 2000; Uličný, 2004; Stewart, 2005). In these large foresets grainflow and grainfall processes led to the accumulation and preservation of characteristic aeolian dune lee slope deposits (e.g. Mountney, 2006a,b; cf. Howell and Mountney, 2001, their Fig. 1B). Grainflow deposits appear as brown tabular 


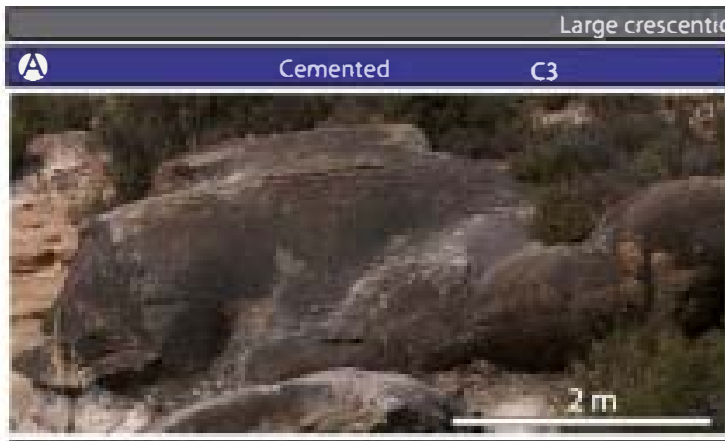

Pitita

B

Aeolian dune toeset-interdune transition
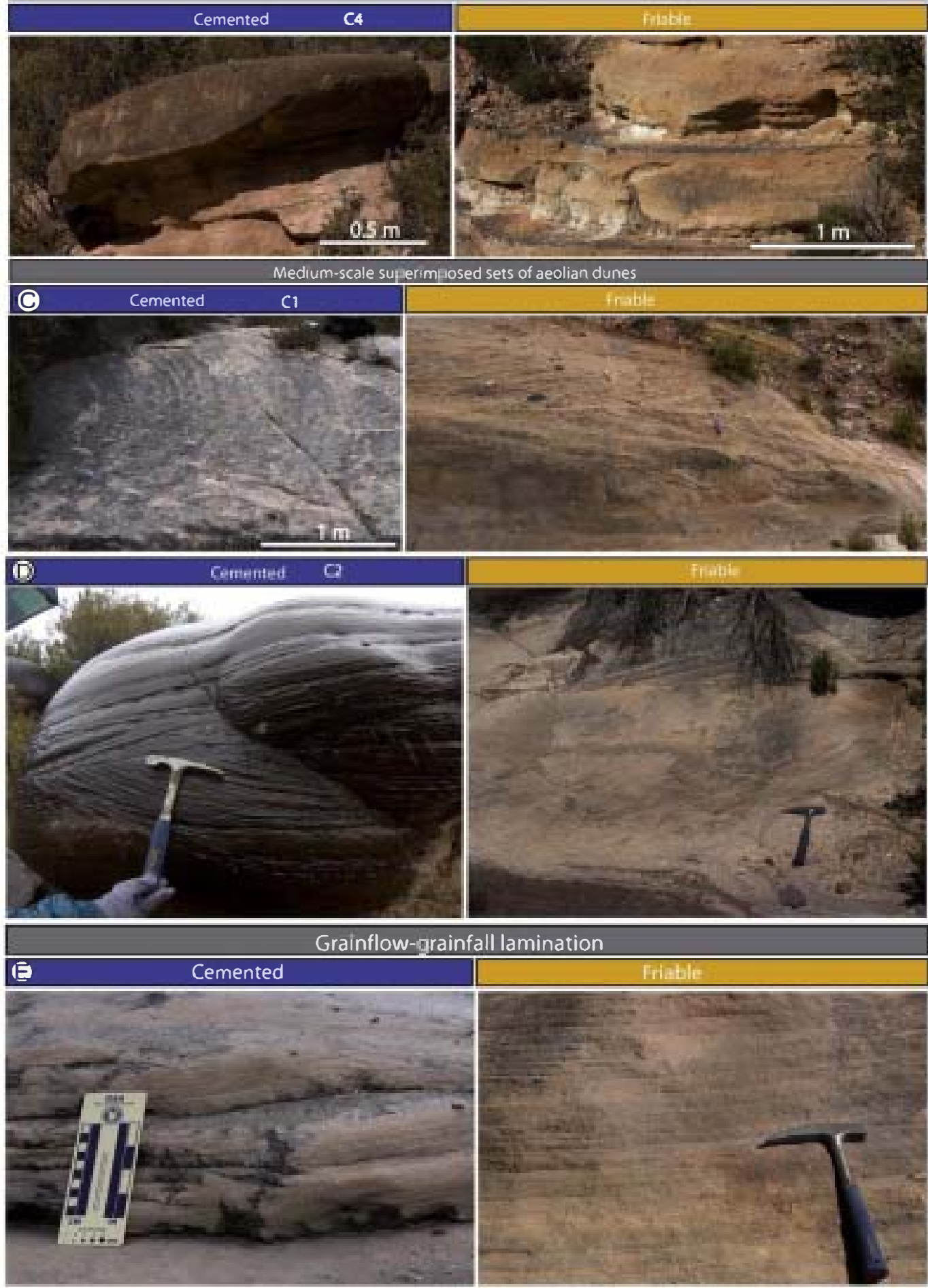
laminae interbedded with thinner and lighter pale-brown grainfall laminae (Fig. 5A). This aeolian element hosts giant calcite concretion C3 (Fig. 6A).

\subsection{Water-table controlled aeolian dune toeset-damp interdune}

\subsubsection{Description}

This facies consists of fine-grained, very well sorted sandstones with wavy-laminated layers forming laterally continuous and tabular intervals (Figs. 5B and 6B). These sandstones merge upwind with the large-scale aeolian dune foresets described above (Fig. 4).

\subsubsection{Interpretation}

These aeolian deposits that occur down-palaeowind of the large foresets are aeolian dune apron deposits. Similar wavy lamination has been described by Mountney and Thompson (2002) and Veiga and Spalletti (2007) in damp, water-table controlled interdunes. This element hosts giant calcite concretion C4 (Fig. 6B).

\subsection{Medium-scale superimposed aeolian dune sets}

\subsubsection{Description}

This element is formed by fine- and medium-grained, very well sorted sandstones arranged in superimposed trough-cross-bedded sets (Fig. 5C) interbedded with the large-scale aeolian dune foresets described above. Sets are separated by sub-parallel downwinddipping surfaces, marked " $\mathrm{S}$ " in Fig. 4, which truncate underlying cross-strata. Individual sets are $0.5 \mathrm{~m}$ thick and display tangential toesets downlapping over the underlying bounding surfaces. Internally, every set consists of laterally continuous lamination very similar to that observed in the aeolian dune foreset described above. Lamination displays a rhythmic repetition of centimetre-thick brown lamina and millimetre-thick pale-brown lamina.

\subsubsection{Interpretation}

The stacked sets of cross-bedding bounded by low-angle inclined downwind-dipping surfaces are interpreted as compound cosets of superimposed aeolian dune sets, each internal set being bounded by a superimposition surface (cf. Kocurek, 1981; Rubin, 1987; Mountney and Thompson, 2002; Mountney, 2006a and b; Rodríguez-López et al., 2008). The tangential toesets record the passage of migrating, slightly sinuous-crested aeolian dunes (cf. Kocurek, 1981; Scherer, 2000; Radies et al., 2004). The internal rhythmic lamination in every set was produced by the alternation of grainflow and grainfall typical of aeolian dune deposits (cf. Hunter, 1977). In Fig. 4, superimposed aeolian dune sets are interbedded with large-scale aeolian dune foresets (Fig. 4). Both aeolian dune elements display tangential foresets indicative of migrating crescentic dunes. Thus, the interbedded occurrence of both elements records the migration of compound aeolian dunes (Kocurek, 1996) in which small superimposed crescentic dunes migrated over the underlying large-scale foreset of the main crescentic aeolian dune (Fig. 4). These superimposed dunes developed over the lee slope of the main dune where these were sufficiently large to host them (Kocurek and Ewing, 2005) and due to secondary airflows over the lee slope of the main aeolian dune (e.g. Clemmensen and Blakey, 1989; Rodríguez-López et al., 2008).

This element hosts giant calcite concretions $\mathrm{C} 1$ (Fig. 6C) and $\mathrm{C} 2$ (Fig. 6D). The original grainflow and grainfall lamination has been preserved within the giant concretions (Fig. 6E).

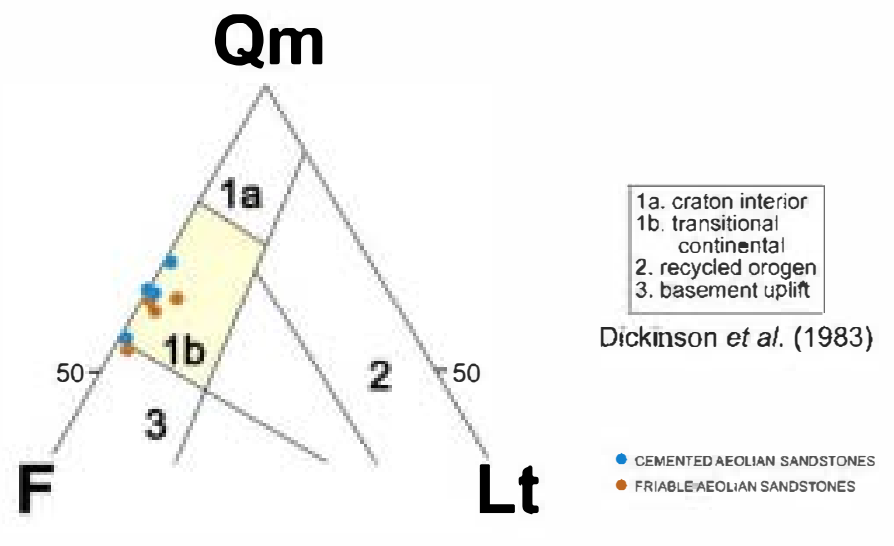

FINE - MEDIUM SAND

Fig. 7. Compositional diagram (QmFLt) of the framework sandstones following Diclinson et al (1983). Qm: Quartz; F: K-feldspar and plagioclase; Lt: metamorphic rock fragments (Lm) and sedimentary rock fragments (Ls)

\subsection{Dry interdunes}

\subsubsection{Description}

Dry interdunes consist of fine-grained, very well sorted sandstones, typical with a white colour in the field (Fig. 5D). They are arranged in tabular and laterally continuous intervals over tens of metres and interbedded with water-table controlled aeolian dune toeset-damp interdune deposits (Fig. 4). Internally this aeolian element is formed by finely laminated sandstones with subcritically climbing translatent strata (Hunter, 1977) (Fig. 5D).

\subsubsection{Interpretation}

Tabular intervals of fine-grained sandstones with subcritically climbing translatent strata have been interpreted as dry interdunes formed by wind ripple migration and accumulation (Hunter, 1977; Kocurek, 1981; Rubin and Hunter, 1982). The style of pinch-out of this element, merging laterally with toesets and foresets (Fig. 4) demonstrates that both deposits are coeval (Fig. 4).

\section{Texture and framework composition of aeolian sandstones}

The aeolian sandstones comprise well sorted fine- to mediumgrained arenites $(\mathbf{L m}=$ Lower medium to $U f=$ Upper fine; Table 1 ). Sandstone bodies have a very homogeneous texture throughout the erg succession (Fig. 8). Locally cementation has produced giant concretions (CAS, Cemented Aeolian Sandstones) (Figs. 9 and 10).

The framework composition in both friable and cemented sandstones reflects a quarzofelsphatic petrofacies $\left(\mathrm{Qm}_{61} \mathrm{~F}_{37} \mathrm{Lt}_{2}\right.$; Fig. 7) characterizing them as arkoses and subarkoses (Pettijohn et al., 1987). Quartz grains include both undulatory and non-undulatory monocrystalline and polycrystalline grain typologies (metaquartzite, chert, etc.; Table 1). Some quartz grains show inherited overgrowth cement (Fig. 9A). Windblown quartz grains are well sorted and sometimes display rounded edges (Fig. 8D) showing upturned plates (Fig. 10C) (e.g. Rodríguez-López et al., 2006). K-feldspar is the most abundant feldspar (23-9\%, Table 1; Figs. 8 and 9), though plagioclase (albite) is also present ( $1 \%$, Table 1$)$. Two $\mathrm{K}$-feldspar populations are distinguished. One consists of clear and idiomorphic crystals, and the

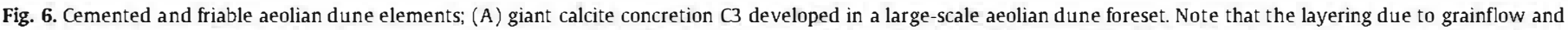

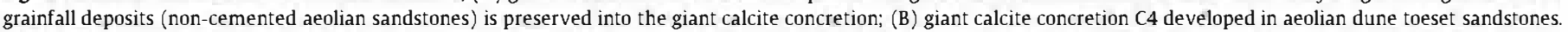

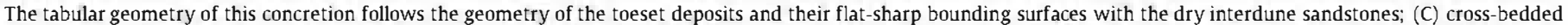

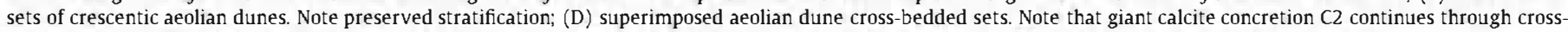
bedded sets and displays spheroid geometry. (E) Cemented grainflow and grainfall deposits with preserved lamination in non-cemented aeolian sandstones. 

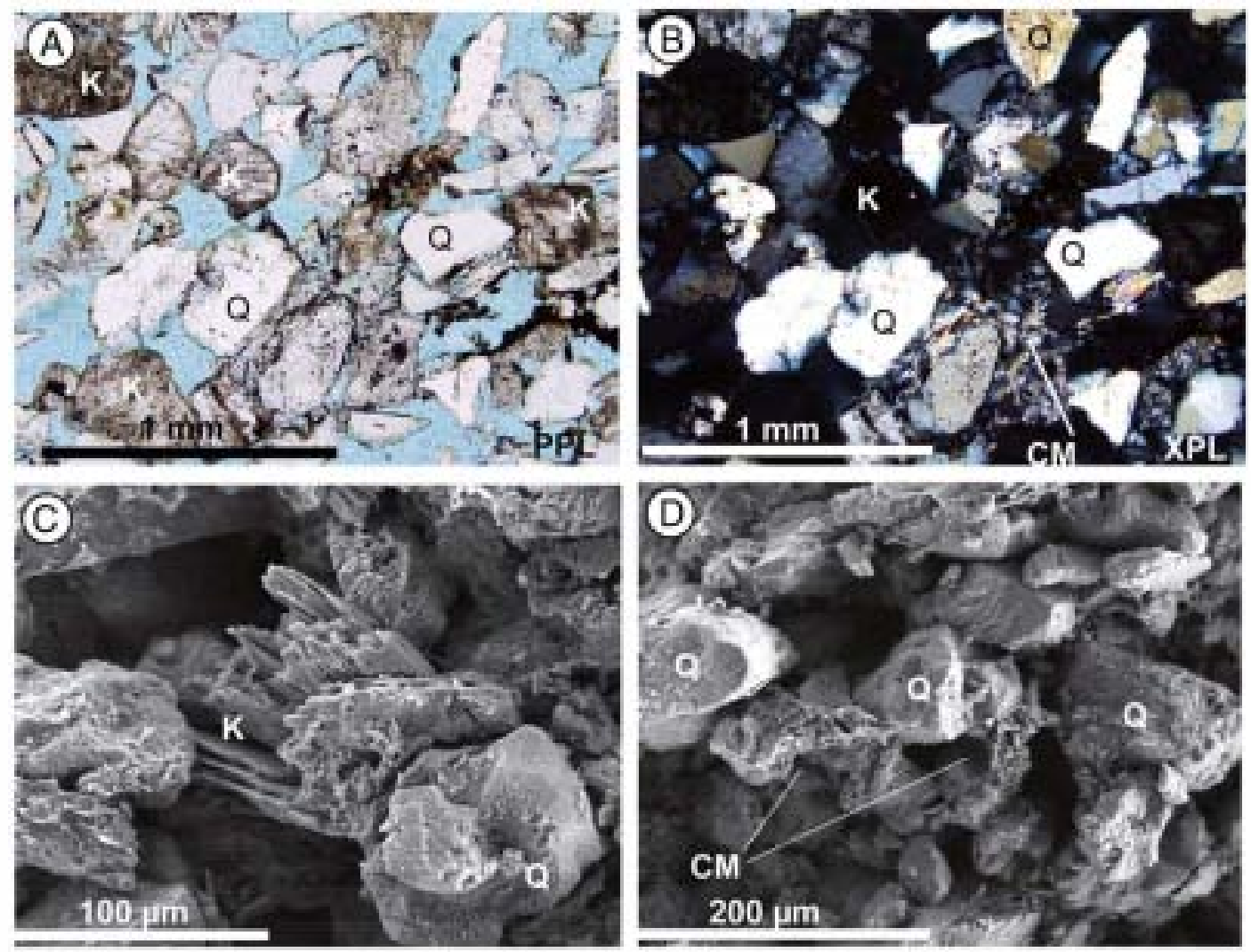

Fig. 8. Friable aeolian sandstone (FAS). (A) Thin section photomicrograph of quartzof eldspathic petrofacies with abundant K-feldspar grains (K) and quartz (Q) (sample C2-2). Mechanically compacted framework reflected in the IGVreduction. PPL, Plane-polarized light; (B) the same view as (A) with cross-polarized light (XPL). Pseudomatrix formation (CM) from labile low-grade metamorphic rock fragments. (C) SEM photomicrograph showing dissolution of K-feldspar (K), rounded quartz (Q) grain, and clay minerals covering grains Observe the high secondary porosity. (D) SEM photomicrograph showing aggregates of clay minerals (CM) in the intergranular volume and as clay rims coated grains. Note the high roundness of the quartz grains and the high porosity between them.

other consists of monocrystalline grains affected by weathering (Fig. 8A and B). Feldspar grains appear corroded by calcite cement in CAS (Figs. 9 and 10) and are partially dissolved in FAS (Fig. 8A and C). Furthermore quartz grains in FAS have been slightly dissolved (Fig. 8) and in CAS they have been slightly corroded by calcite cement (Fig. 10). Opaque grains are significant components in the sandstone framework (up to $12 \%$, Table 1), and they are mainly concentrated in the foreset laminae. Some of these opaque grains have been deformed by mechanical compaction. Rock fragment grains are very variable in nature and include micaschists, slates, coarse-grained rock fragments (plutonites), metasediments and sedimentary rock fragments (sandstones) (Table 1 ). Minor detrital components $(<4 \%)$ are: muscovite, biotite, chlorite, tourmaline, zircon and other heavy minerals. In CAS "ghost grains" appear as the nuclei of poikilotopic crystal cements (Fig. 9A and B), showing a bright luminescence (BL, yellow/orange; (Fig. 9C and D)), which contrasts with the non-luminescent poikilotopic calcite cement. This contrast permits the deduction of an inherited luminescence signal in the "ghost grains" (core), suggesting an original carbonate grain core.

\section{Diagenesis of aeolian sandstones}

\subsection{Clay coatings and Fe-oxide cement}

Opaque Fe-oxide cement, with coats and meniscus textures, is characteristic in all sampled aeolian sandstones (Fig. 11A). Minor amounts of clay minerals covering the grain surfaces are demonstrated by fluorescence microscopy (FM) (Fig. 11B). These clay rims are difficult to recognize under plane polarized light because they are masked by opaque Fe-oxide cement (Fig. 11A). They show a yellow fluorescence (Fig. 11B), similar to illite rims described by Lemon and Cubitt (2003). In addition, clay minerals have been observed coating framework grains under SEM (Figs. 8D and 10D). According to Krystinik (1990a), these types of coatings can be interpreted as the result of the redistribution of very fine aeolian dust around grains after rainfall, leading to a thin "crust" over the grains. Chemical alteration due to the interaction with sporadic meteoric water may produce slight alterations of $\mathrm{K}$-feldspar grain surfaces leading to the formation clay minerals as dioctahedral smectite (McKinley et al., 2003). In addition, smectite is the dominant product during the early and intermediate stage of rock weathering (Chesworth, 1977). Smectite minerals preferentially form during weathering of granitic rocks under arid climate conditions, and smectite was reported to be the dominant clay-mineral weathering product in modern desert environments (Chamley, 1989).

Upon evaporation different precipitates may form, including amorphous silica, clay minerals, iron and alumina oxides, and hydroxides (Krystinik, 1990a). These types of clay coatings are the first diagenetic products in the original arenite in the Iberia example.

Fe-oxide coatings form opaque cement and appear locally with meniscus textures. This type of opaque cement may be the result of the oxidation of iron released from framework grains. Framework grains as biotite and muscovite with opaque mineral concentrations within cleavage planes occur. These grains may have contributed to the formation of coatings and of opaque meniscus cements as amorphous orange-red iron and alumina oxides-hydroxide precipitates (cf. Walker, 1979). A similar clay and iron coating association has been described for the aeolian Navajo Sandstone by Parry et al. (2009). Both cements, clay coatings and Fe-oxides, pre-date later mechanical compaction and calcite cementation. 

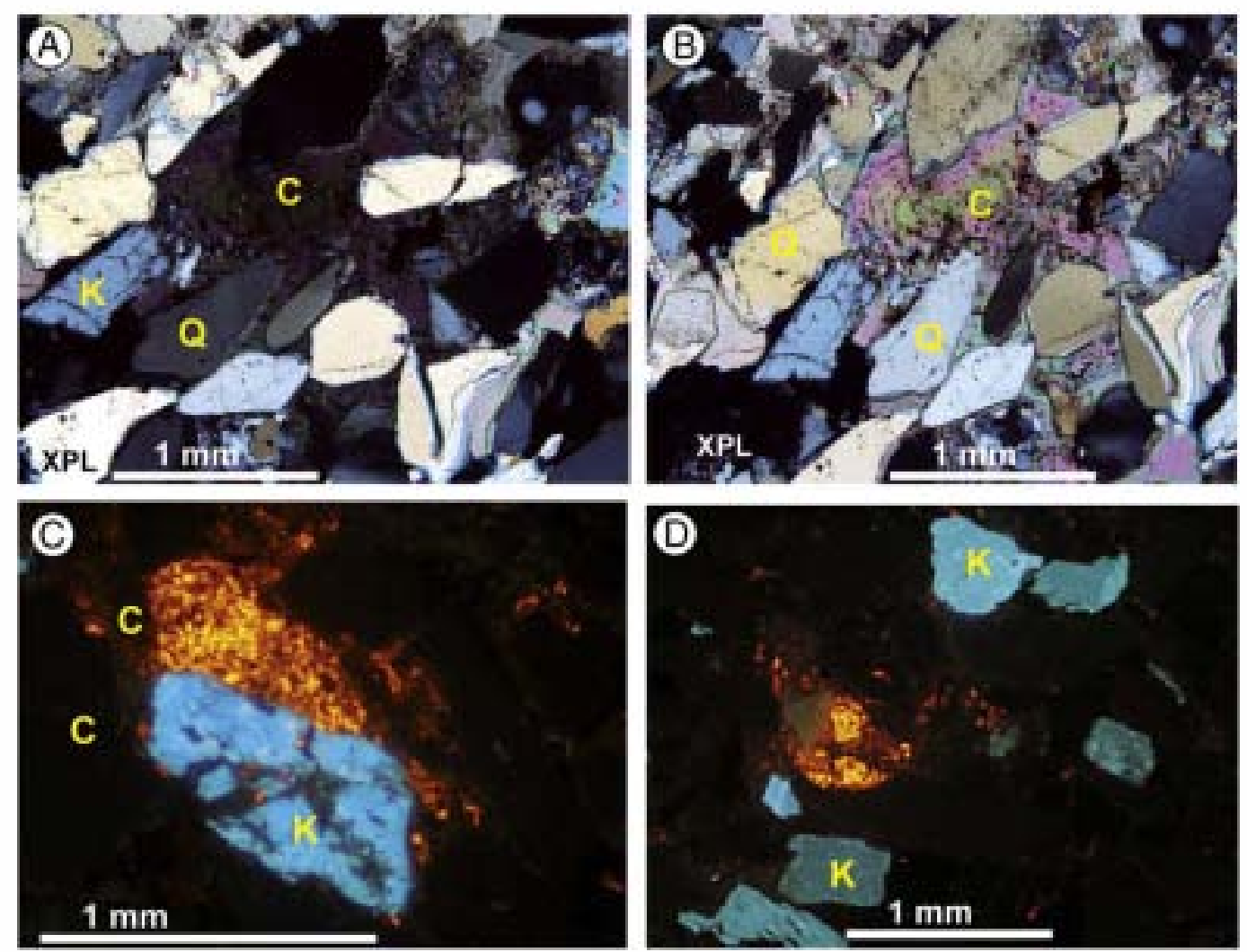

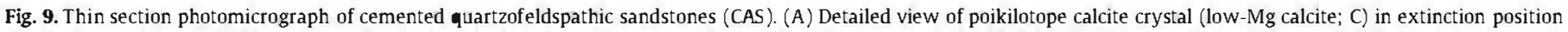

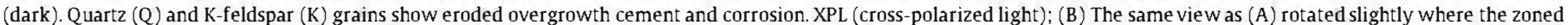

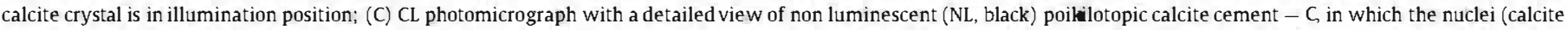

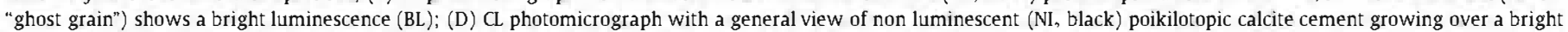
luminescent (BL) calcite nuclei. Note the bright luminescent nuclei (calcite "ghost grain") which reproduce the shape and roundness of the original clast.

\subsection{Calcite cement: poikilotopic and mosaic textures}

Calcite cement occurs as poikilotopic and coarse spar mosaics, and is responsible for the development of the giant calcite concretions (CAS) in the aeolian sandstones. Poikilotopic crystals nucleated from carbonate grains (Fig. 9). Calcite crystals mostly exceed $2 \mathrm{~mm}$ length and a few reach $4 \mathrm{~mm}$. Many calcite crystals are zoned emphasizing the euhedral habit of the nuclei (Figs. 9B and 10B). Individual calcite crystals vary from very cloudy (near to nuclei) to clear (away from the nuclei) (Figs. 12 and 13). Poikilotopic calcite cement is present only in the giant concretions, postdating earlier diagenetic processes (clay coatings, Fe-oxides, and early mechanical compaction), obscuring the remnant intergranular porosity.

Electron microprobe data show non-ferroan calcite (Tables 2 and 3). The chemical composition of the two samples is very similar and corresponds to low $\mathrm{Mg}$-calcite. $\mathrm{SrCO}_{3}$ is less than $0.1 \mathrm{~mol} \%$ or absent. Further, the amounts of $\mathrm{MgCO}_{3}$ (mean $=0.38 \mathrm{~mol} \%$ ), $\mathrm{MnCO}_{3}($ mean $=0.07 . \mathrm{mol} \%)$, and $\mathrm{FeCO}_{3}($ mean $=0.44 . \mathrm{mol} \%)$ are low. The highest values for $\mathrm{MnCO}_{3}$ are found in the cores (calcite ghost grain) of the poikilotopic calcite crystals, where luminescence is bright (Fig. 9C and D). These high values decrease drastically towards the border of the crystal. The Fe content in some nuclei of poikilotopic calcite crystals shows a relatively high value ( $1 \mathrm{~mol} \%$ in analysis no. 1, Fig. $12 \mathrm{C}$ and Table 2), and also near the grain border $(1.63 \mathrm{~mol} \%$ in analysis no. 14 , Fig. $13 \mathrm{C}$ and Table 3 ) where opaque coating occurs. McBride and Milliken (2006) presented geochemical composition data of early calcite cements in similar carbonate concretions comparable with the values recorded in this study. All values are also closely comparable with those proposed by Veizer (1983) for the theoretical average composition of diagenetic low $\mathrm{Mg}$-calcite precipitated from meteoric waters.

\subsection{Mechanical compaction}

Both CAS (concretions) and FAS (host rock) show evidence of compaction. The sandstone framework has been affected by mechanical compaction, manifested by the presence of pseudomatrix, formed by the deformation of ductile grains such as slates and shaly intraclasts (Fig. 8A and B). Muscovite grains also experienced mechanical compaction, this being one of the most important controls for the loss of original porosity. Petrographic IGV analysis and the estimation show a greater porosity loss by compaction (COLP, Lundegard, 1992) in FAS than in CAS (Table 1).

\section{Porosity and intergranular volume (IGV)}

Friable aeolian sandstones (FAS) display a high porosity and are easily eroded. Their cohesion as seen in outcrop is due to clay rims and iron oxides coatings. In FAS, total porosity varies between 19 and $30.6 \%$ with an average of $23.8 \%$ (Table 1). Pores are the result of the combination of the remaining intergranular porosity (primary porosity) after compaction, plus secondary pores generated by the dissolution of framework grains. Locally pores are isolated and oversized, i.e., larger than the medium grain size. This type of porosity is ascribed to framework-grain dissolution. For calculation of the intergranular volume (IGV), porosity in FAS was recalculated taking into account the dissolution of grains.

In the giant calcite concretions (CAS) porosity varies between $2.3 \%$ and $4 \%$. Porosity is both primary and secondary. The values obtained with the Hg-porosimeter are slightly higher, $2.9 \%-8.4 \%$. This is because this technique also measures the microporosity. In CAS, the IGV prior to cementation was estimated on the basis of the volume occupied by calcite cement plus the residual intergranular porosity 

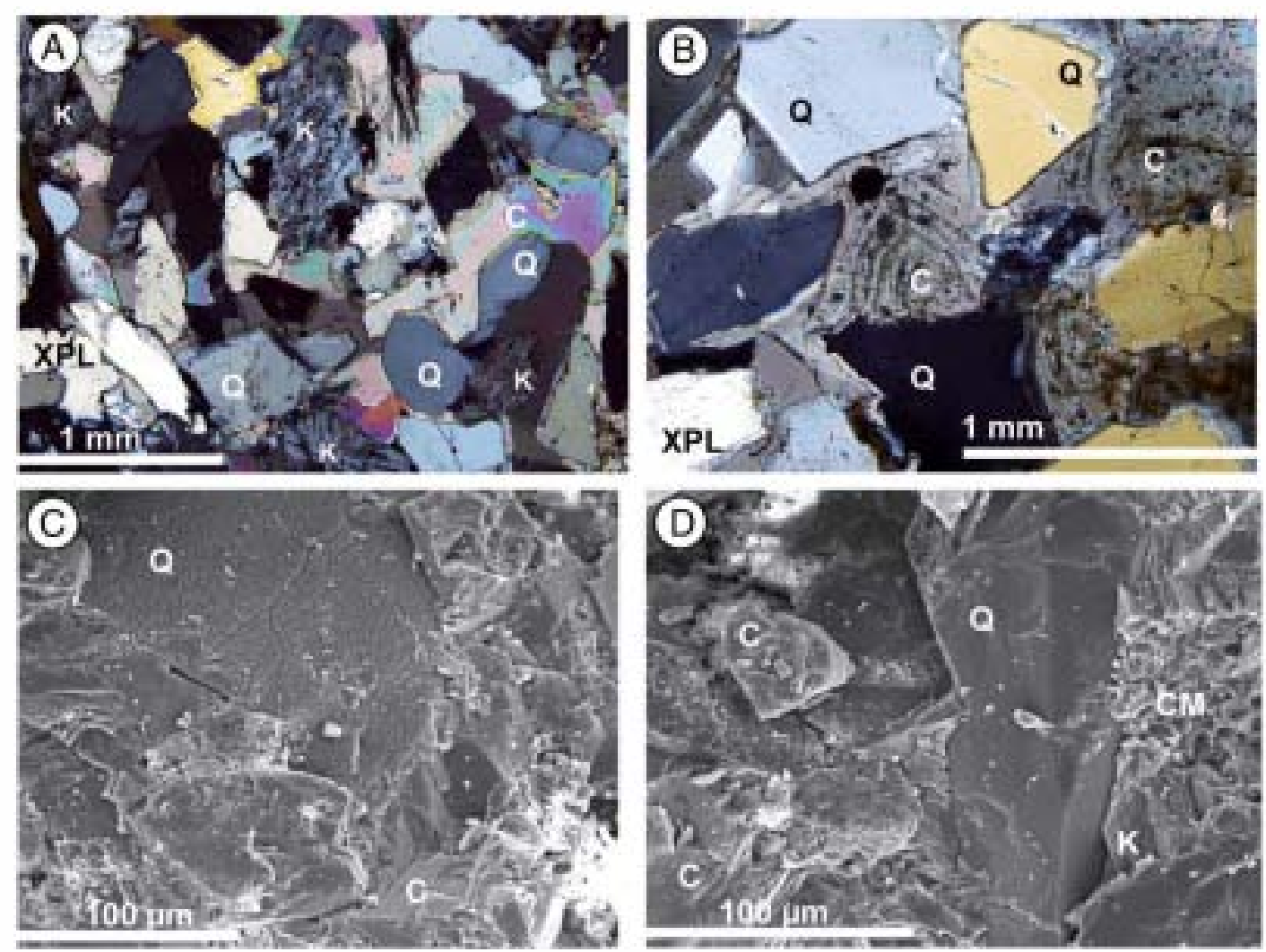

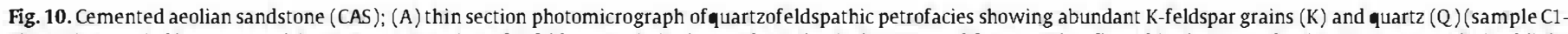

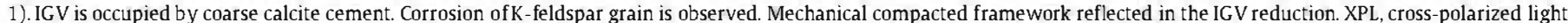

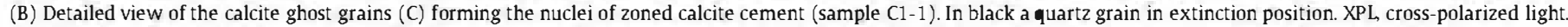

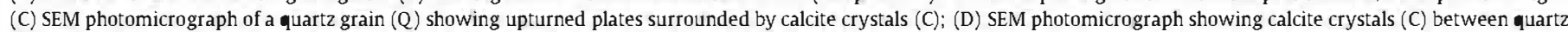
(Q) and K-feldspar (K) grains. In the right of the image chemical transformation of K-feldspar grain to clay minerals (CM).

(Table 1). The carbonate nuclei (ghost grains) were counted as original framework. The pre-cementation IGV in the four giant calcite concretions shows a slight increase from C1 to C4 (Fig. 14).

Considering the grain size (lower medium to upper fine) and the well to very well sorted nature (Rodríguez-López et al., 2006) of both FAS and CAS (Table 1), the original aeolian arenites would have had an original porosity close to $\sim 40 \%$ (cf. Beard and Weyl, 1973). This value was used to estimate the porosity loss following Lundegard (1992) (Fig. 14). The IGV in FAS ranges from $7.3 \%$ to 15.3\% (Table 1 and Fig. 14), in CAS from 18.6\% to 25.3\% (Table 1 and Fig. 14).

The FAS therefore shows a greater porosity loss by mechanical compaction, so that in CAS the IGV values are higher. This indicates that calcite cementation in giant concretions post-dates early mechanical compaction, and pre-dates late mechanical compaction in FAS. In FAS mechanical compaction was more intense, whereas in CAS calcite cementation inhibited mechanical compaction.

\section{Architectural and sedimentological control on the geometry of the giant calcite concretions}

The four giant calcite concretions occur in four different levels of the second erg sequence of the mid-Cretaceous Iberian Desert System (Figs. 1F, 2, 3, 4). This second erg sequence developed upon a tectonic-related regional aeolian super-surface and is characterized by both complex and compound aeolian dune deposits (RodríguezLópez et al. 2008). In the Barranco del Colocho Section, this erg system consists of a variety of aeolian facies arranged in aeolian dune cross-bedded sets that merge laterally into interdune deposits. A hierarchy of aeolian bounding surfaces is observed and each giant calcite concretion is related with a specific aeolian element (Figs. 2-4).
The lowermost giant concretion (C1) displays a tabular geometry, is $4 \mathrm{~m}$ thick and extends over an area of more than $324 \mathrm{~m}^{2}$ (Fig. 2). This concretion is developed in crescentic aeolian dune sandstones and spans several aeolian dune cross-bedded sets and thus including bounding interdune surfaces (Fig. 6C). The cementation zone is bounded by main interdune surfaces in which a porosity and permeability barrier exist. This giant concretion displays a maximum expansion parallel to interdune surfaces and a minimum development in the perpendicular direction (Fig. 15A and B). The result is a tabular and laterally continuous giant concretion (Fig. 2).

Giant calcite concretion C2 has an elliptical geometry, is $1 \mathrm{~m}$ thick and $2 \mathrm{~m}$ long (Figs. 3 and 4 ), the extension within the outcrop not being known, and developed in superimposed sets of aeolian dune deposits (Fig. 6D). This giant calcite concretion displays trough cross-bedded sets. Both the top and base are downwind dipping parallel surfaces that coincide with parallel aeolian superimposition surfaces (Fig. 15C and F). The flat superimposition surfaces at the base and top mark the cementation limit (Figs. 3 and 4).

Giant calcite concretion C3, the second largest giant calcite concretion, displays an elliptical-tabular geometry with a sharp base and top, and is more than $2 \mathrm{~m}$ thick and more than $6 \mathrm{~m}$ wide (Figs. 3 and 4). It developed in large-scale aeolian dune foreset sandstone. Well preserved continuous lamination can be followed laterally over a distance of $6 \mathrm{~m}$ (Fig. 6A). The base coincides with a slightly downwind dipping superimposition surface and the top with a laterally continuous downwind dipping reactivation surface. The resultant geometry is a wedge-shaped concretion with sharp boundaries.

The topmost concretion, C4, is $0.5 \mathrm{~m}$ thick and has a tabular geometry. It developed in water-table controlled aeolian dune toeset-damp interdune sandstones (Fig. 6B) interbedded with dry interdune deposits. Base and top coincide with interdune flooding surfaces and 

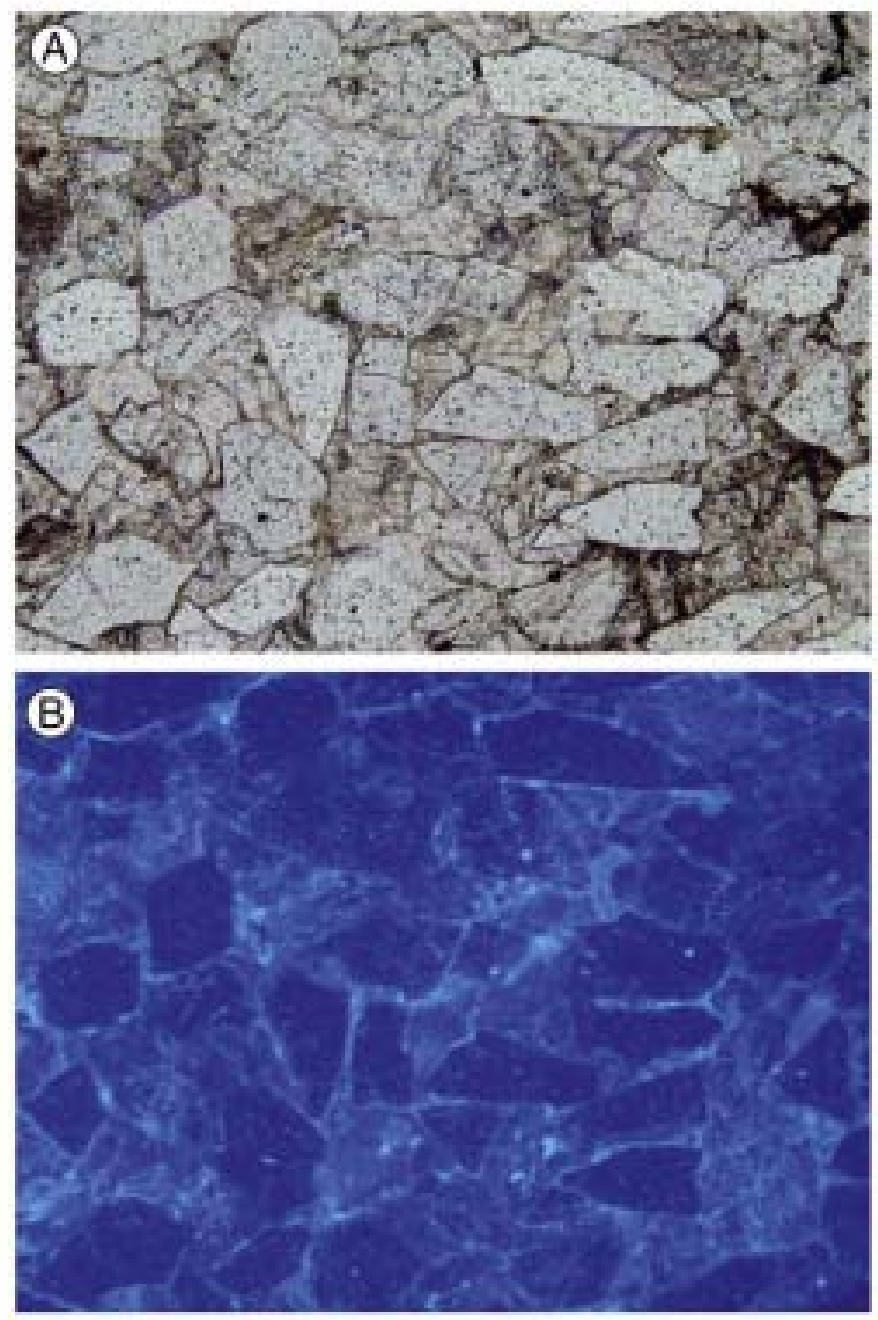

Fig. 11. (A) Thin section photomicrograph illustrates the quartzof eldspathic petrofacies of a CAS ( $\mathrm{Cl}$ concretion, $\mathrm{Cl}-3$ sample); grains correspond to quartz (Q) and K-feldspar (K); IGV is occupied by calcite cement which corroded to the grains. Grains are coated by opaque clay rims; PPL, Plane-polarized light. (B) The same view as (A) viewed in fluorescence mode. The bright coatings correspond to clay mineral luminescent yellow. Some K-feldspar grains present luminescence in the exfoliation plane probably due to the chemical transformation to illite.

surfaces associated with dune-interdune pinch out (see RodríguezLópez et al., 2008).

Similar elongate calcite concretions oriented subparallel to bedding and tabular stratum have been described by Beckner and Mozley (1998) in aeolian dune deposits. These authors interpreted these concretions as the result of cementation in the phreatic zone on the basis of poikilotopic and blocky spar cements in coarser and better sorted sandstones and preservation of original sedimentary structures.

\section{Discussion}

\subsection{Framework composition and provenance}

Aeolian sandstones are commonly mature in composition (quartzarenites) $0.09 \mathrm{pt}$ ? > due to factors such as multiple cycling and persistent aeolian abrasion (Krystinik, 1990b). Immature sandstones, such as arkoses and subarkoses with labile and metastable grains (K-feldspar, etc.) also have been described for aeolian dune systems (Schenk, 1990; McBride and Milliken, 2006). These latter sandstones reflect first-cycle sources with possibly multiple lithologies (Krystinik, $1990 \mathrm{~b})$. In the Iberian erg system the quartzofeldspathic petrofacies reflects a dominant first-order supply, mainly from coarse crystalline rocks (plutonites), the Variscan (Hesperian) Massif to the west (Rodríguez-López et al., 2010). Sandstones plot in the 'transitional continental' to 'basement uplift' fields (Fig. 7) in the compositional diagram (QmFLt) of Dickinson et al. (1983). Also, the presence of a minor population of metamorphic and sedimentary rock fragments, as well as feldspar and quartz grains with partly eroded overgrowth cement, indicate an additional source area of low-grade to mediumgrade metamorphic and sedimentary rocks. These types of grains have been described by Arribas et al. (2007) in both sedimentary and metamorphic petrofacies in the Iberian Basin. The widespread occurrence of "clean" and not altered K-feldspar is a consequence of the arid conditions under which mid-Cretaceous sedimentation occurred (Rodríguez-López et al., 2008). The quartzofeldspathic petrofacies coincides with petrofacies JC-4 of Arribas et al. (2007) in early Cretaceous sandstones in the Cameros Basin (Iberian Ranges, Spain). As suggested by these authors, this petrofacies is indicative of a first-cycle plutonic origin (Dickinson et al., 1983). Coarse crystalline rocks from the Hesperian Massif in the Central Iberian Zone would have been the principal source of these petrofacies (Arribas et al., 2003, 2007). An additional source from metasediments covering the acid-plutonic basement is expected based on the additional presence of a significant population of metamorphic and sedimentary rock fragments in the quartzofeldspathic sandstones.

\subsection{Development of the giant-calcite concretions; implications for aeolian reservoir properties}

The major diagenetic processes influencing porosity in sandstones took place during early diagenesis, and include the formation of clay coatings and Fe-oxide cement, progressive mechanical compaction, partial dissolution of $\mathrm{K}$-feldspar, and calcite cementation. Clay coatings and Fe-oxide cement represent the first phase of cementation and are responsible for cohesion and slight lithification of the framework sandstones (Fig. 11). Clay coatings of illite on sand grains are also observed as an earliest diagenetic product in the Jurassic aeolian Navajo Sandstone (Parry et al., 2009). The most general environmentrelated diagenetic feature in ancient desert aeolian dune sandstones are thin films of clay around grains (Seemann, 1982) as observed in Fig. 11. These early clay films, which were likely sourced via windblown dust, infiltrated mechanically into the aeolian dune sands (Walker, 1979; Seemann, 1982) and played an important role during burial diagenesis because they acted as crystallization nuclei for the formation of and transformation into new clay minerals (Seemann, 1982).

A significant control during diagenesis was the feldspar content of the aeolian sandstone. Occasionally, under more humid conditions, feldspar may undergo chemical changes during early diagenesis, when dissolution and clay mineral transformation occur. Part of the $\mathrm{K}$-feldspar grains shows evidence of such alteration (Fig. 8C). Subsequent early mechanical compaction contributes more easily to the reduction of the IGV (Fig. 14). The different IGV values in aeolian sandstones (FAS and CAS) show that calcite cementation in giant concretions occurs during early burial inhibiting later mechanical compaction. Indeed FAS shows more compaction than the cemented dune sandstones (CAS). These IGV data show that calcite cementation took place during early burial diagenesis. Early diagenesis in the Iberian aeolian sandstones was therefore conditioned by factors as framework composition, porosity of the original aeolian arenite, and phreatic groundwater.

Petrographical and geochemical analysis shows that calcite cementation and the consequent development of giant concretions occurred in highly permeable aeolian sandstones fed by groundwater. A possible compositional control could be the presence of carbonate grains (extraclasts or inherited calcite-replaced feldspar grains) in the framework, which could have acted as nuclei for later phreatic- 

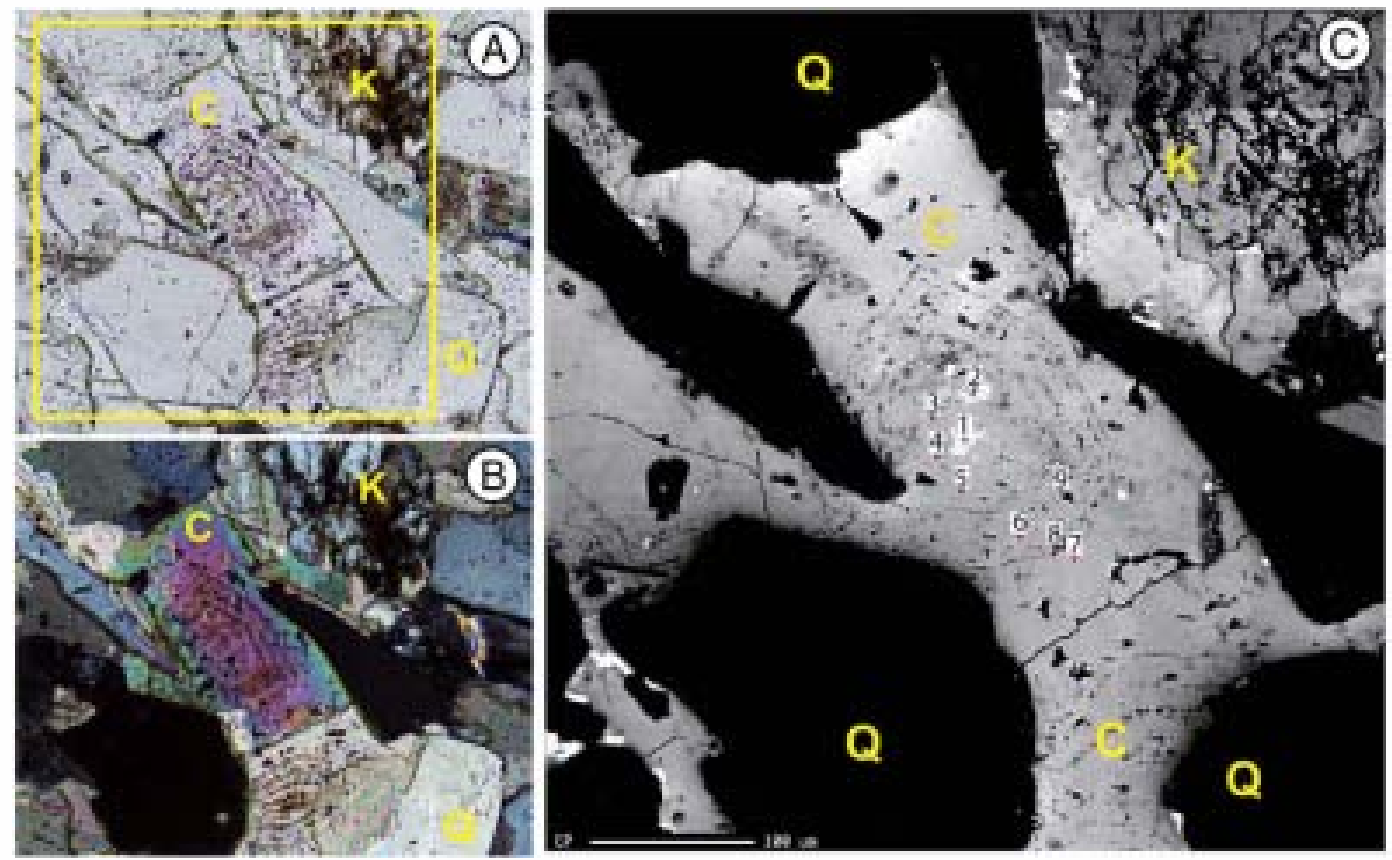

Fig. 12. Photomicrographs illustrating a detailed view of the zoned calcite cement (C) in sample $\mathrm{C} 1-1(5)$; grains correspond to quartz (Q) and $\mathrm{K}$-feldspar (K); (A) plane-polarized light (PPL) and (B) cross-polarized light (XPL). (C) Backscattered electron image (BSE) of the previous detailed view of zoned calcite-cement (A and B). The numbers (1 to 9 ) indicate the electron microprobe analyses points (collected in Table 2). Note the corrosion and partial replacement of the K-feldspar (K) by calcite.
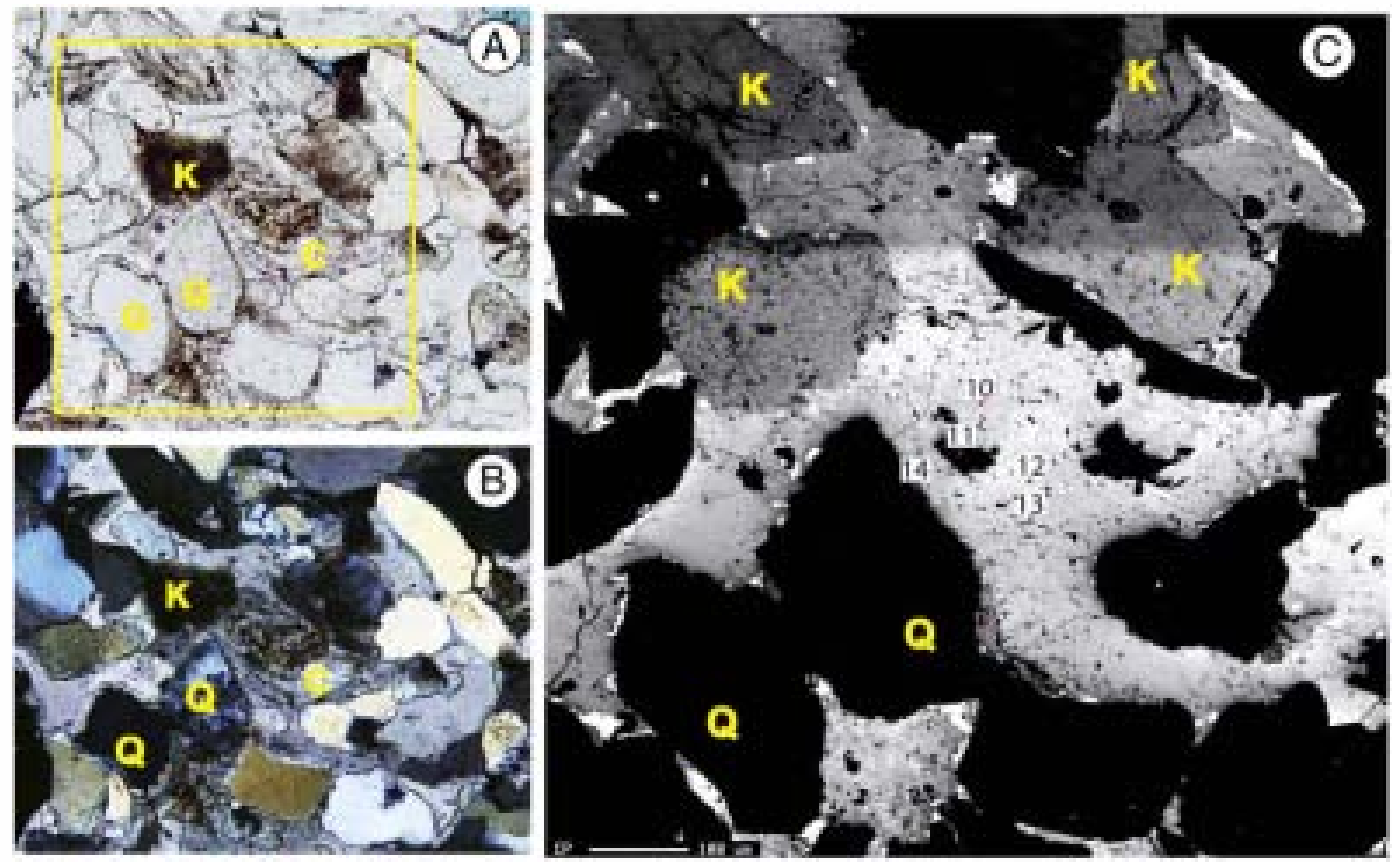

Fig. 13. Photomicrographs illustrating a detailed view of the zoned calcite cement (C) in sample $C 1-1(1)$; grains correspond to quartz (Q) and $K$-feldspar (K); (A) plane-polarized light (PPL) and (B) cross-polarized light (XPL). (C) Backscattered electron image (BSE) of the previous detailed view of zoned calcite-cement (A and B). The numbers (10 to 14) indicate the electron microprobe analyses points (collected in Table 3). Note the corrosion of the K-feldspar (K) and quartz (Q) grains by calcite.

zone precipitation. Calcite cementation could take place locally on carbonate nuclei during early burial diagenesis.

Literature on giant-calcite concretions is scarce. Mechanisms explaining the spatial distribution of giant-calcite concretions in the Temple Member (Eocene Qasr El Sagha Formation, Egypt) were analyzed and discussed by Abdel-Wahab and McBride (2001) and they suggested that carbonate shell fragments may have served as the nuclei for giant concretions. However, in the Iberian erg, aeolian dunes are barren of carbonate shell fragment and the poikilotopic crystals in the intergranular pores nucleated from carbonate rock fragments (extraclasts or inherited calcite-replaced feldspar grains). Speculatively, a control based on the spatial distribution of these carbonate rock fragments similar to the spatial distribution of shell fragments in the Temple Member (Eocene Qasr El Sagha Formation, Egypt) is proposed as main control on the spatial distribution of the giant-calcite concretions. Another important similarity with the example of Abdel-Wahab 
Table 2

Electron microprobe analyses points ( 1 to 9 ) from Fig. 12.

\begin{tabular}{|c|c|c|c|c|c|c|c|c|c|}
\hline & 1 & 2 & 3 & 4 & 5 & 6 & 7 & 8 & 9 \\
\hline \multicolumn{10}{|c|}{ Oxides $(\%)$} \\
\hline $\mathrm{SiO}_{2}$ & 0.000 & 0.002 & 0.000 & 0.006 & 0.000 & 0.002 & 0.000 & 0.264 & 0.047 \\
\hline $\mathrm{Na}_{2} \mathrm{O}$ & 0.000 & 0.028 & 0.000 & 0.000 & 0.000 & 0.000 & 0.004 & 0.001 & 0.017 \\
\hline $\mathrm{K}_{2} \mathrm{O}$ & 0.000 & 0.073 & 0.000 & 0.000 & 0.001 & 0.000 & 0.000 & 0.032 & 0.010 \\
\hline $\mathrm{CaO}$ & 3.916 & 3.914 & 3.985 & 3.935 & 3.991 & 3.976 & 3.978 & 3.442 & 3.853 \\
\hline $\mathrm{MgO}$ & 0.028 & 0.027 & 0.011 & 0.019 & 0.005 & 0.013 & 0.015 & 0.010 & 0.005 \\
\hline $\mathrm{MnO}$ & 0.013 & 0.001 & 0.000 & 0.000 & 0.000 & 0.000 & 0.002 & 0.002 & 0.031 \\
\hline $\mathrm{FeO}$ & 0.040 & 0.003 & 0.003 & 0.033 & 0.002 & 0.005 & 0.000 & 0.002 & 0.003 \\
\hline \multirow[t]{2}{*}{ SrO } & 0.002 & 0.003 & 0.001 & 0.001 & 0.002 & 0.003 & 0.002 & 0.000 & 0.000 \\
\hline & 4.000 & 4.051 & 4.000 & 3.994 & 4.001 & 3.998 & 4.000 & 3.753 & 3.996 \\
\hline \multicolumn{10}{|c|}{ Carbonates $(\%)$} \\
\hline $\mathrm{CaCO}_{3}$ & 97.912 & 96.616 & 99.613 & 98.518 & 99.770 & 99.457 & 99.445 & 91.734 & 97.151 \\
\hline $\mathrm{MgCO}_{3}$ & 0.708 & 0.676 & 0.275 & 0.471 & 0.112 & 0.320 & 0.362 & 0.272 & 0.129 \\
\hline $\mathrm{MnCO}_{3}$ & 0.330 & 0.025 & 0.000 & 0.000 & 0.000 & 0.000 & 0.057 & 0.051 & 0.774 \\
\hline $\mathrm{FeCO}_{3}$ & 1.003 & 0.074 & 0.075 & 0.836 & 0.057 & 0.120 & 0.000 & 0.040 & 0.078 \\
\hline \multirow[t]{2}{*}{$\mathrm{SrCO}_{3}$} & 0.040 & 0.079 & 0.022 & 0.028 & 0.040 & 0.063 & 0.042 & 0.000 & 0.000 \\
\hline & 99.992 & 97.47 & 99.985 & 99.852 & 99.98 & 99.96 & 99.908 & 92.096 & 98.131 \\
\hline
\end{tabular}

Table 3

Electron microprobe analyses points (10 to 14) from Fig. 13.

\begin{tabular}{lclrrr}
\hline & 10 & 11 & 12 & 13 & \multicolumn{1}{l}{14} \\
\hline Oxides (\%) & & & & & \\
$\mathrm{SiO}_{2}$ & 0.000 & 1.997 & 0.001 & 0.001 & 0.055 \\
$\mathrm{Na}_{2} \mathrm{O}$ & 0.002 & 0.0014 & 0.001 & 0.005 & 0.017 \\
$\mathrm{~K}_{2} \mathrm{O}$ & 0.000 & 0.000 & 0.000 & 0.002 & 0.008 \\
$\mathrm{CaO}$ & 3.979 & 0.004 & 3.983 & 3.980 & 3.795 \\
$\mathrm{MgO}$ & 00.08 & 0.000 & 0.014 & 0.012 & 0.016 \\
$\mathrm{MnO}$ & 0.005 & 0.000 & 0.000 & 0.000 & 0.003 \\
$\mathrm{FeO}$ & 0.005 & 0.000 & 0.000 & 0.000 & 0.065 \\
$\mathrm{SrO}$ & 0.002 & 0.000 & 0.000 & 0.001 & 0.000 \\
& 4.000 & 2.002 & 3.999 & 4.001 & 3.958 \\
& & & & & \\
$\mathrm{Carbonates}^{(\%)}$ & & & & & \\
$\mathrm{CaCO}_{3}$ & $\mathbf{9 9 . 4 6 3}$ & & $\mathbf{9 9 . 5 9 2}$ & $\mathbf{9 9 . 4 6 8}$ & $\mathbf{9 5 . 8 8 6}$ \\
$\mathrm{MgCO}_{3}$ & 0.192 & & 0.355 & 0.305 & 0.397 \\
$\mathrm{MnCO}_{3}$ & 0.125 & & 0.000 & 0.000 & 0.073 \\
$\mathrm{FeCO}_{3}$ & 0.122 & & 0.010 & 0.000 & 1.635 \\
$\mathrm{SrCO}_{3}$ & 0.060 & & 0.005 & 0.032 & 0.000 \\
& $\mathbf{9 9 . 9 6 3}$ & & $\mathbf{9 9 . 9 6 2}$ & $\mathbf{9 9 . 8 0 5}$ & $\mathbf{9 7 . 9 9 1}$ \\
\hline
\end{tabular}

and McBride (2001) is the necessity of a stable hydrological regime over a long period of time. These authors pointed out that solute supply solely by diffusion cannot account for the size of larger concretions in the time available for concretion growth. Thus these authors indicated that most concretion growth took place when solute was supplied by fluid flow. Fluid flow must also have been a key control on the development of the Iberian giant-calcite concretions. The Iberian erg system was located between the Variscan Iberian Massif to the west and the Tethys Ocean to the east. The back-erg system close to the desert highlands (Iberian Massif) received ephemeral water influxes that led to erosion of aeolian dune sands and desert pavements forming hyperconcentrated flows (Rodríguez-López et al., 2010). Considering the lack of any signs of fluvial activity in the central erg and fore-erg deposits, these water fluxes must have quickly infiltrated into the subsurface and fed the regional groundwater system. For instance, in the Eastern Desert, Egypt, during the 1994 flood event, the groundwater recharge through transmission losses ranged from $21 \%$ to $31 \%$ of the precipitated volume (Gheith and Sultan, 2002). Groundwater flows in the Sahara range from 0.2 to $2 \mathrm{~m} / \mathrm{yr}$ (Sturchio et al., 2004) or from 0.2 to $0.5 \mathrm{~m} / \mathrm{yr}$ (Guendouz and Moulla, 2006). Taking into account that the giant-calcite concretions developed during early diagenesis under the influence of meteoric waters, a similar desert ground water flow likely favoured the development of the Cretaceous giant-calcite concretions. However, such process should favour a more widespread occurrence of giant calcite concretions than observed. Local activity of fluid flow through extensional faults either in or not in combination with variations of the phreatic level associated with e.g. more or less water influx to the erg system and varying sea level could have favoured the local development of giant-calcite concretions.

\subsection{Aeolian reservoir heterogeneity; the role of bounding surfaces}

Ancient windblown deposits form volumetrically significant reservoirs (Glennie, 1986), e.g. the Permian Slochteren Formation that constitutes the main reservoir in the NE Netherlands (Hern et al., 2001) and the Jurassic Norphlet Sandstone (offshore Gulf of Mexico, USA), which produces natural gas from depths in excess of $6.4 \mathrm{~km}$ (Taylor et al., 2004).

Maximizing recovery of fluids from these reservoirs requires an understanding of the scales of fluid-flow heterogeneity within the depositional system (Kirschbaum and Schenk, 2011). For instance,

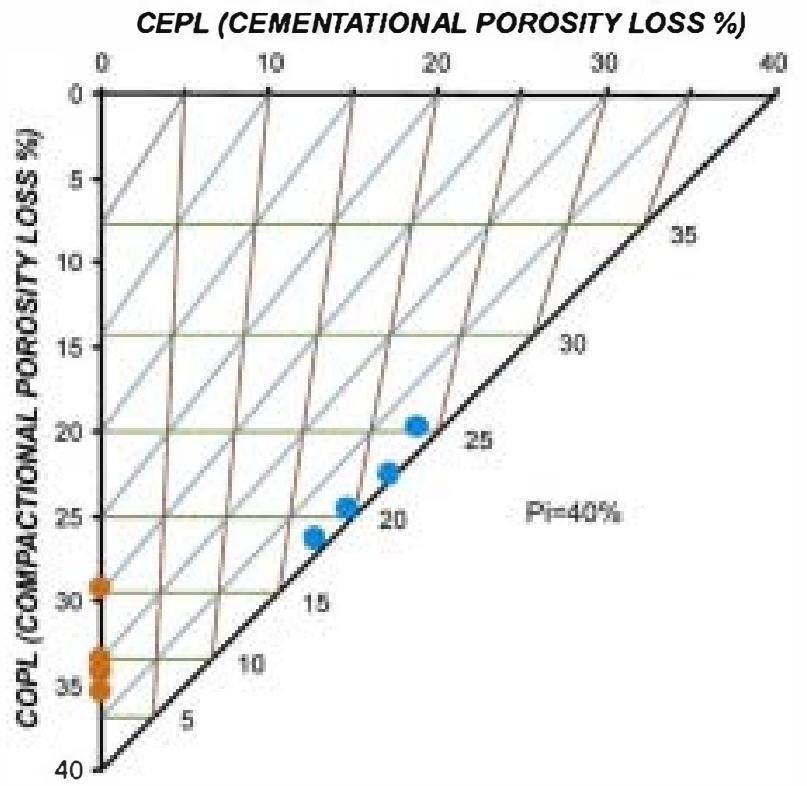

Fig. 14. Ludengard diagram. COLP: compactional porosity loss, CEPL: cementational porosity loss. $\mathrm{Pi}(40 \%)$ is the original porosity estimated according to Beard and Weyl (1973). 

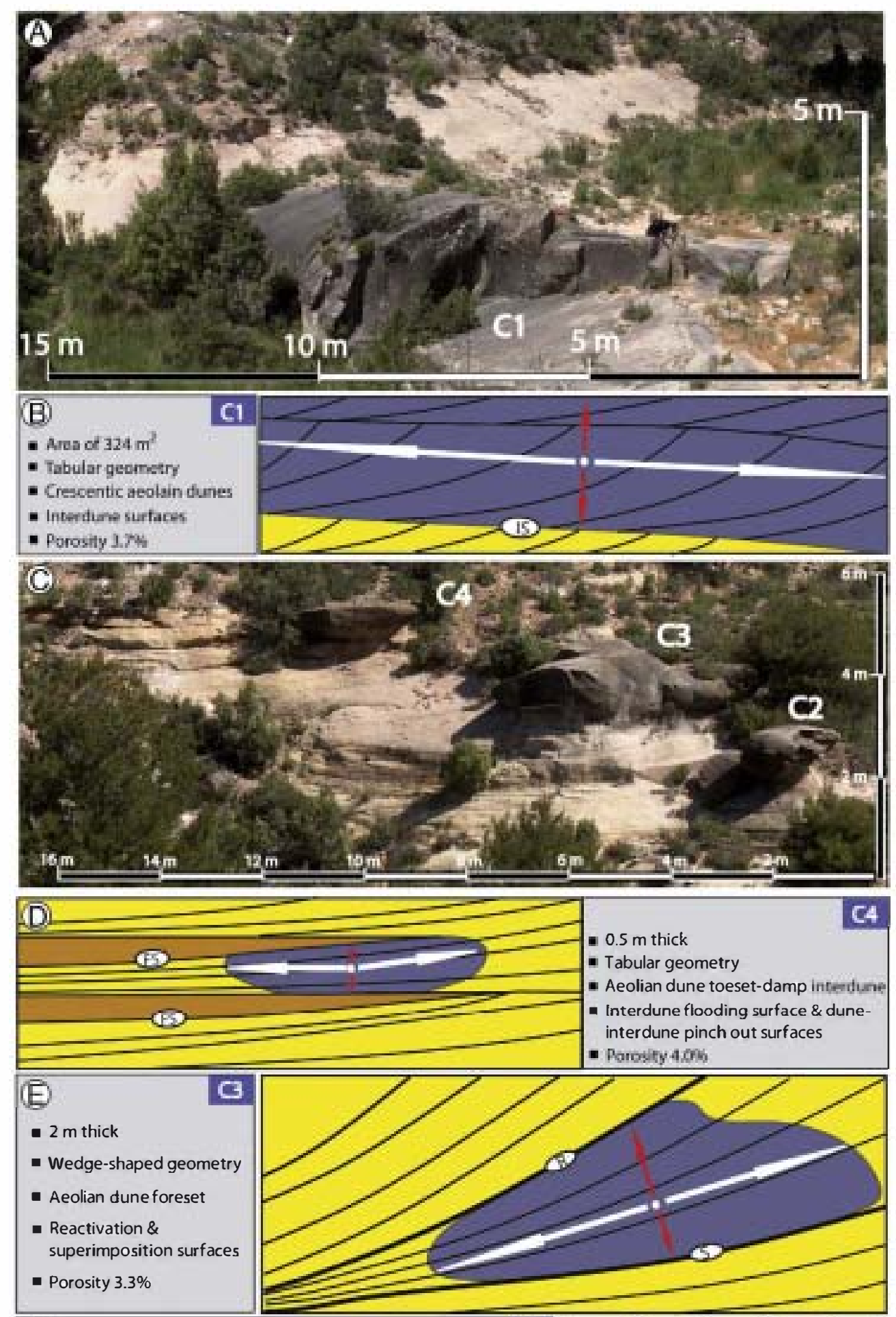

- I $\mathrm{m}$ thick
- Ellipsoidal geometry
Superimposed aeolian
dune sandstones
aeolian sandstones
giant-calcite concretions

Fig. 15. (A) Field photograph of giant calcite concretion $\mathrm{C} 1$. (B) Main characteristics and geometrical control by interdune surfaces on concretion $\mathrm{C}$. (C) Field photograph of giant calcite concretions $\mathrm{C} 2-\mathrm{C} 4$. (D-F) Main characteristics and geometrical controls by different aeolian bounding surfaces on cementations $\mathrm{C} 2-\mathrm{C} 4$ 
thus porosity is 8.3 times less. The giant calcite concretions bounded by superimposition and reactivation surfaces have a less continuity and lateral extent than those bounded by interdune surfaces. Superimposition and reactivation surfaces are bounded by interdune surfaces (Mountney, 2006a,b). Obviously, in this case, concretion shape and dimension will be controlled by the geometrical relationship and set thickness, which is bounded by the superimposition and reactivation surfaces. Giant calcite concretions with less lateral continuity are those associated with flooding surfaces (Fig. 16A) (which lead to a significant porosity reduction (from $20.7 \%$ to $4 \%$ ) in the case of concretion (4). Again, the lateral continuity of the flooding surfaces and the permeability of the water-laid deposits covering it, will exert a key control on the giant calcite concretion morphology and extent and thus determining the heterogeneity distribution in the aeolian reservoir (Fig. 16B).

\section{Conclusions}

Giant calcite concretions developed locally in aeolian dune sandstones in the Mid-Cretaceous Iberian desert system during early burial diagenesis, are associated with the groundwater system of a desert basin which was regularly recharged from the adjacent highlands. The major diagenetic processes that influenced the porosity of the aeolian sandstones took place during early diagenesis. These processes included the development of clay coatings around grains, the development of Fe-oxide cement, the progressive mechanical compaction, the chemical dissolution of $\mathrm{K}$-feldspar, and the calcite cementation. The FAS show the most pronounced porosity loss due to mechanical compaction, whereas in CAS the IGV porosity values remained higher because calcite cementation in giant concretions pre-dated mechanical compaction. In FAS, mechanical compaction reduced porosity from $\sim 40 \%$ to between $15 \%$ and $20 \%$, whereas in CAS early cementation prevented significant compaction.

The quartzofeldspathic petrofacies in the Iberian erg sandstones are indicative of a dominant first-cycle plutoniclastic origin, and demonstrate derivation from coarse crystalline rocks from the Central Iberian Zone in the Hesperian (Variscan) Massif. This composition determined characteristic diagenetic processes in the aeolian sandstones including the formation of clay coatings, chemical transformation of $\mathrm{K}$-feldspar to pseudo-matrix and $\mathrm{K}$-feldspar dissolution.

The geometry of the different giant calcite concretions is associated with the main bounding aeolian surfaces. The spatial distribution of these surfaces controlled the shape of the concretions and thus the spatial distribution of diagenetic heterogeneities in the aeolian reservoir.

\section{Acknowledgements}

The authors are grateful to Editor G.J. Weltje. We are grateful to Dr. Nigel Mountney and anonymous reviewers for their helpful comments and suggestions. The authors are also grateful to Dr. José Arribas for his suggestions and recommendations. This paper is a contribution to project CGI2008-05418 (Ministerio de Ciencia e Innovación, MICINN, of the Spanish Govemment).

\section{References}

Abdel-Wahab, A., Mcbride, E.F., 2001. Origin of giant calcite-cemented concretions, Temple Member, Quasr El Sagha Formation (Eocene). Journal of Sedimentary Research $71,70-80$.

Arribas, J., Alonso, A., Mas, R., Tortosa, A., Rodas, M., Barrenechea, J.F., Alonso-Azcárate, J., Artigas, R., 2003. Sandstone petrography of continental depositional sequences of an interpolate rift basin: Western Cameros Basin (North Spain). Journal of Sedimentary Research 73, 309-327.

Arribas, J., Ochoa, M., Mas, R., Arribas, Mª.E., González-Acebrón, L., 2007. Sandstone petrofacies in the northwestern sector of the Iberian Basin. Journal of Iberian Geology 33, 191-206.
Beard, D.C., Weyl, P.K., 1973. Influence of texture on porosity and permeability of unconsolidated sand. AAPG Bulletin 57, 349-369.

Beckner, J.R., Mozley, P.S., 1998. Origin and spatial distribution of early vadose and phreatic calcite cements in the Zia Formation, Albuquerque Basin, New Mexico, USA. Special Publication of International Association of Sedimentologists 26 , 87-105.

Bjorkum, P.A., Walderhaug, O., 1990. Geometrical arrangement of calcite concretions within shallow marine sandstone. Earth-Science Reviews 29, 145-161.

Brookfield, M.E., 1977. The origin of bounding surfaces in ancient aeolian sandstones. Sedimentology 24, 303-332.

Chamley, H., 1989. Clay sedimentology. Springer, Berlin, Heidelberg, New York. 623 pp.

Chesworth, W., 1977. Weathering stages of the common igneous rocks, index minerals and minerals assemblages at the surface of the earth. Journal of Soil Science 28 , $490-497$.

Chumacov, N.M., Zharkov, M.A., Herman, A.B., Doludenko, M.P., Kalandadze, N.N., Lebedev, E.L, Ponomarenko, A.G., Rautian, A.S., 1995. Climatic belts of the mid-Cretaceous time. Stratigraphy and Geological Correlation 3, 241-260.

Clemmensen, L.B., Blakey, R.D., 1989. Erg deposits in the Iower Jurassic Wingate Sandstone, northeastern Arizona: oblique dune sedimentation. Sedimentology 36, 449-470.

Dickinson, W.R., Beard, L.S., Brakenridge, G.R., Erjavec, J.L., Ferguson, R.C., Inman, K.F., Knepp, R.A., Lindberg, F.A., Ryberg, P.T., 1983. Provenance of North American Phanerozoic sandstones in relation to tectonic setting. Geological Society of America Bulletin 94, 222-235.

Friedman, G.M., 1971. Staining. In: Arver, R.E. (Ed.), Procedures in Sedimentary Petrology. Wiley, New York, pp. 511-530.

Gheith, H., Sultan, M., 2002. Construction of a hydrologic model for estimating Wadi runoff and groundwater recharge in the Eastem Desert, Egypt. Joumal of Hydrology 263, 36-55.

Glennie, K.W., 1986. Development of N.W. Europe's Southern Permian Gas Basin. In: Brooks, J., Goff, J.C., van Hoorn, B. (Eds.), Habitat of Palaeozoic Gas in N.W. Europe. Geological Society of London Special Publication, Edinburg, pp. 3-22.

Glennie, K.W., Buller, A.T., 1983. The Permian Weissliegend of NW Europe: the partial deformation of aeolian dune sands caused by the Zechstein transgression. Sedimentary Geology 35, 43-81.

Guendouz, A., Moulla, A.S., 2006. The Shared Resources in the North-Western SaharaAquifer System (Algeria-Tunisia-Libya): The use of Environmental Isotopes (Algeria part) Intemational Conference "Transboundary Aquifers: Challenges and New Directions" (ISARM2010), UNESCO, París, pp. 1-4.

Hern, C., Nordlund, U., van der Zwan, K., Iadipo, K., 2001. Forward prediction of aeolian systems using fuzzy logic, constrained by data from recent and ancient analogues. Geologie en Mijnbow 80, 53-70.

Heward, A.P., Schofield, P., Gluyas, J.G., 2003. The Rotliegend reservoir in Block 30/24, UK Central North Sea: including the Argyll (renamed Ardmore) and Innes fields. Petroleum Geoscience 9, 295-307.

Howell,JA., Mountney, N.P., 2001. Aeoliangrain flow architecture: hard data for reservoir models and implications for red bed sequence stratigraphy. Petroleum Geoscience ?, 51-56.

Hunter, R.E., 1977. Basic types of stratification in smalleolian dunes. Sedimentology 24 , 361-387.

Ingersoll, R.V., Bullard, T.F., Ford, R.L., Grimm,J.P., Pickle,J.D., Sares, S.W., 1984 . The effect of grain size on detrital modes: a test of the Gazzi-Dickinson point-counting method. Journal of Sedimentary Petrology 54, 103-116.

Jarosewich, E., Nelen, J.A., Norberg, J.A., 1980. Reference samples for electron microprobe analysis. Geostandards Newsletters 4, 43-47.

Kirschbaum, M.A., Schenk, C.J., 2011. Sedimentology and reservoir heterogeneity of a valley-fill deposit-a field guide to the Dakota Sandstone of the San Rafael Swell, Utah. U.S. Geological Survey Scientific Investigations Report, 2010-5222. 36 pp.

Kocurek, G., 1981. Significance of interdune deposits and bounding surfaces in aeolian dune sands. Sedimentology 28, 753-780.

Kocurek, G., 1991. Interpretation of ancient eolian sand dunes. Annual Review of Earth and Planetary Sciences 19, 43-75.

Kocurek, G., 1996. Desert aeolian systems. In: Reading, H.G. (Ed.), Sedimentary Environments: Processes. Facies and Stratigraphy, Blackwell Science, Oxford, pp. $125-153$.

Kocurek, G., Ewing, R., 2005. Aeolian dune field self-organization - implications for the formation of simple versus complex dune-field patterns. Geomorphology 72, 94-105.

Krystinik, LF., 1990a. Early diagenesis in continental Eolian deposits. In: Fryberger, S.G., Krystinik, L.F., Schenk, Ch.J. (Eds.), Modern and Ancient Eolian Deposits: Petroleum Exploration and Production, Rocky Mountain Section, SEPM, Denver, Colorado, USA, pp. 8.1-8.11.

Krystinik, L.F., 1990b. Diagenesis in continental eolian deposits. In: Fryberger, S.G., Krystinik, L.F., Schenk, Ch.J. (Eds.), Modern and Ancient Eolian Deposits: Petroleum Exploration and Production, Rocky Mountain Section, SEPM, Denver, Colorado, USA, pp. 14.1-14.14

Kugler, R.L., Mink, R.M., 1999. Depositional and diagenetic history and petroleum geology of the Jurassic Norphlet Formation of the Alabama Coastal Waters area and adjacent federal waters area. Marine Georesources and Geotechnology 17, 215-232.

Lancaster, N., 1995. Geomorphology of Desert Dunes. Routledge, United Kingdom.

Lemon, N.M., Cubitt, C.J., 2003. Illite fluorescence microscopy: a new technique in the study of illite in the Merrimelia Formation, Cooper Basin, Australia In: Worden, R.H., Morad, S. (Eds.), Clay Mineral Cements in Sandstones, 34. IASSpecial Publication, pp. 411-424.

Liesa, C.L., Casas, A.M., Soria, A.R., Simón,J.L., Meléndez, A., 2004. Estructura extensional cretácica e inversión terciaria en la región de Aliaga-Montalbán (Cordillera Ibérica). Geo-Guías, 1, pp. 151-180. 
Linholm, R.C., Finkelman, R.B., 1972. Calcite staining; semiquantitative determination of ferrous iron. Journal of Sedimentary Research 42 (1), 239-242.

Lundegard, P.D., 1992. Sandstone porosity loss; a "big picture" view of the importance of compaction. Journal of Sedimentary Petrology 62, 250-260.

McBride, E.F., Milliken, K.L, 2006. Giant calcite-cemented concretions, Dakota Formation, central Kansas, USA. Sedimentology 53, 1161-1179.

McBride, E.F., Picard, M.D., Milliken, K.L, 2003. Calcite-cemented concretions in sandstone, Cretaceous, Wyoming and Utah. Joumal of Sedimentary Research 73, 462-483.

McKee, E.D., 1979. Ancient sandstones considered to be eolian. In: McKee, E.D. (Ed.), A Study of Global Sand Seas: GeoL Soc. Am. Spec. Pap., voL 1052, pp. 189-238.

McKinley, J.M., Worden, R.H., Ruffell, A.H., 2003. Smectite in sandstones: a review of the controls on occurrence and behavior during diagenesis. Int. Assoc. SedimentoL Spec. Publ 34, 109-128.

Milliken, K.L, 1998. Carbonate diagenesis in non-marine foreland sandstones at the western edge of the Alleghanian overthrust belt, Southern Appalachians. Special Publication of International Association of Sedimentologists 26, 87-105.

Mountney, N.P. (2006a) Eolian facies models. In: Walker, R.G., Posamentier, H. (Eds.), Facies models revisited. SEPM Memoir, 84, pp.19-83.

Mountney, N.P., 2006a. Periodic accumulation and destruction of aeolian erg sequences in the Permian Cedar Mesa Sandstone, White Canyon, southern Utah, USA. Sedimentology 53, 789-823.

Mountney, N.P., Thompson, D.B., 2002. Stratigraphic evolution and preservation of aeolian dune and damp/wet intendune strata: an example from the Triassic Helsby Sandstone Formation, Cheshire Basin, UK. Sedimentology 49, 805-833.

Mountney, N.P., Jagger, A., 2004. Stratigraphic evolution of an aeolian erg margin system: the Permian Cedar Mesa Sandstone, SE Utah, USA. Sedimentology 51, 713-743.

Morad, S., Al-Ramadan, Ketzer, K.J.M., De Ros, L.F., 2010. The impact of diagenesis on the heterogeneity of sandstone reservoirs: a review of the role of depositional facies and sequence stratigraphy. AAPG Bulletin 94, 1267-1309.

Norman, M.B., 1974. Improved techniques for selective staining of feldspar and other minerals using amaranth. U.S. Geological Survey, Journal Research 2, 73-79.

Parry, W.T., Chan, M.A., Nash, B.P, 2009. Diagenetic characteristics of the Jurassic Navajo Sandstone in the Covenant Oil Field, Central Utah thrust belt. AAPG Bulletin 93, 1039-1061.

Petrijohn, F.J., Potter, P.E, Siever, R., 1987. Sand and Sandstones. Springer-Verlag, New York

Radies, D., Preusser, F., Matter, A., Mange, M., 2004. Eustatic and climatic controls on the development of the Wahiba Sand Sea, Sultanate of Oman. Sedimentology 51 $1359-1385$.

Rodríguez-López, J.P., de Boer, P.L., Meléndez, N., Soria, A.R., Pardo, G., 2006. Windblown desert sands in coeval shallow marine deposits a key for the recognition of coastal ergs; mid-Cretaceous Iberian Basin, Spain. Terra Nova 18, 314-320.

Rodríguez-López, J.P., Meléndez, N., De Boer, P.L., Soria, A.R., 2008. Aeolian sand sea development along the Mid-Cretaceous Western Tethyan Margin (Spain): erg sedimentology and palaeoclimate implications. Sedimentology 55, 1253-1292.

Rodríguez-López, J.P. Meléndez, N., De Boer, P.L, Soria, A.R., 2010. The action of wind and water in a mid-Cretaceous subtropical erg-margin system close to the Variscan Iberian Massif, Spain. Sedimentology 57, 1315-1356.

Rodríguez-Iópez,J.P., Meléndez, N., De Boer, P.L., Soria, A.R., in press. Controls on marineerg margin cycle variability: aeolian-marine interaction in the mid-Cretaceous Iberian Desert System, Spain. Sedimentology. doi: 10.1111/j.1365-3091.2011.01261.x (Article first published online: 13 JUN 2011).

Rubin, D.M., 1987. Cross-bedding, bedforms and palaeocurrents. SEPM Concepts in Sedimentology and Paleontology 1, 187.

Rubin, D.M., Hunter, R.E., 1982. Bedform climbing in theory and nature. Sedimentology 29, $121-138$.
Schenk, C.J, 1990. Overview of eolian sandstone diagenesis, Upper Jurassic Denkman Sandstone Member of the Norphlet Formation, Mississippiand Alabama. In: Fryberger, S.G., Krystinik, LF., Schenk, Ch.J. (Eds.), Modern and Ancient Eolian Deposits: Petroleum Exploration and Production. Rocky Mountain Section, SEPM. Denver, Colorado, USA, pp. 20.1-20.12.

Scherer, C.M.S., 2000. Eolian dunes of the Botucatu Formation (Cretaceous) in southernmost Brazil: morphology and origin. Sedimentary Geology 137, 63-84.

Seemann, U., 1982. Depositional facies, diagenetic clay minerals and reservoir quality of Rotliegend sediments in the Southern Permian Basin (North Sea): a review. Clay Minerals 17, 55-67.

Spicer, B., Skelton, P.W., 2003. The operation of the major geological carbon sinks. In: Skelton, P.W. (Ed.), The Cretaceous World. Cambridge University Press, pp. 249-271.

Stampfli, G.M., Borel, G.D., 2002. A plate tectonic model for the Paleozoic and Mesozoic constrained by dynamic plate boundaries and restored synthetic oceanic isochrones. Earth and Planetary Science Letters 196, 17-33.

Stewart, J.H., 2005. Eolian deposits in the Neoproterozoic Big Bear Group, San Bernardino Mountains, California, USA. Earth-Science Reviews 73, 47-62.

Strömbäck, A., Howell, J.A., Veiga, G.D., 2005. The transgression of an erg-sedimentation and reworking/soft-sediment deformation of aeolian facies: Cretaceous Troncoso Member, Neuquén Basin, Argentina. In: Veiga, G.D., Spalletti, L.A., Howell, J.A., Schwarz, E. (Eds.), The Neuquén Basin,Argentina: A Case Study inSequenceStratigraphyand Basin Dynamics, The Geological Society of Iondon, Special Publication, 252, pp. 163-183.

Sturchio, N.C., Du, X., Purtschert, R., Iehmann, B.E., Sultan, M., Patterson, L.J., Lu, Z.-T., Mü ller, P., Bigler, T., Bailey, K., O'Connor, T.P., Young, L., Lorenzo, R., Becker, R., El Alfy, Z, El Kaliouby, B., Dawood, Y., Abdallah, A.M.A., 2004. One million year old groundwater in the Sahara revealed by krypton-81 and chlorine-36. Geophysical Research letters 31 (L05503), 1-4

Taggart, S., Hampson, G.J., Jackson, M.D., 2010. High-resolution stratigraphic architecture and lithological heterogeneity within marginal aeolian reservoir analogues. Sedimentology $57,1246-1279$

Taylor, T.R., Stancliffe, R., Macaulay, C., Hathon, L, 2004. High temperature quartz cementation and the timing of hydrocarbon accumulation in the Jurassic Norphlet Sandstone, offshore Gulf of Mexico, U.S.A. In: Cubitt, J.M., England, W.A., Iarter, S.R. (Eds.), Understanding Petroleum Reservoirs; Toward an Integrated Reservoir Engineering and Geochemical Approach: The Geological Society of Iondon: Special Publication, 237 , pp. $257-278$.

Uličný, D., 2004. A drying-upward aeolian system of the Bohdašin Formation (Early Triassic), Sudetes of NE Czech Republic: record of seasonality and long-term palaeoclimate change. Sedimentary Geology 167, 17-39.

Veiga, G.D., Spalletti, L.A., 2007. The Upper Jurassic (Kimmeridgian) fluvial-aeolian systems of the southern Neuquén Basin, Argentina. Gondwana Research 11, 286-302.

Walderhaug, O., Bjorkum, P.A., 1998. Calcite cement in shallow marine sandstones: growth mechanisms and geometry. Special Publication of International Association of Sedimentologists 26, 179-192.

Walker, T.R., 1979. Red colour in dune sand. In: McKee, E.D. (Ed.), A Study of Global Sand Seas: USGS Prof. Paper, 1052. 429 pp.

Veizer, J., 1983. Chemical diagenesis of carbonates: theory and application of trace element technique. Stable isotopes in sedimentary geology. SEPM Short course 10 , $1-100$. 